\title{
REVISÃO DE ALCHISME KIRKALDY (HEMIPTERA, MEMBRACIDAE, MEMBRACINAE, HOPLOPHORIONINI) ${ }^{1}$
}

\author{
Antonio J. Creão-Duarte ${ }^{2}$ \\ Albino M. Sakakibara ${ }^{3}$
}

\begin{abstract}
Revision of Alchisme Kirkaldy (Hemiptera, Membracidae, MemBRACINAE, HOPLOPHORIONINI). Thirty four (34) species of Alchisme Kirkaldy, 1904 are presented with descriptions, illustrations, and key for identification, except for two of them which were not seen, A. truncaticornis (Germar, 1835) and A. intermedia (Distant, 1881). The following nomenclatural changes are introduced: Achisme intermedia (Distant, 1881), sp. rev.; A. testacea (Fairmaire, 1846), sp. rev.; Alchisme apicalis (Walker, 1851) = A. costaricensis Goding, 1929, syn.n.; A. inermis (Fairmaire, 1846) $=$ Triquetra nigrocarinata Fairmaire, 1846 , syn.n.; A. rubrocostata $($ Spinola, $1852)=$ A. neuquina Remes-Lenicov, 1978, syn.n.; A. turrita $($ Germar, 1835) $=$ Triquetra submaculata Buckton, 1901, syn.n.; A. ustulata $($ Fairmaire, 1846) $=$ Triquetra virgata Fairmaire, 1846, syn.n.; A. virescens (Fairmaire, 1846) = Alchisme spinosa Funkhouser, 1940, syn.n.; Alchisme banosiensis sp.n. (from Ecuador); A. bordoni sp.n. (from Venezuela); A. colombiana sp.n. (from Colombia); A. salta sp.n. (from Argentina); A. cultellata sp.n. (from Venezuela); A. deflexa sp.n. (from Venezuela); A. erecta sp.n. (from Venezuela); A. frontomaculata sp.n. (from Brazil); A. goiana sp.n. (from Brazil); $A$. henryi sp.n. (from Venezuela); $A$. insolita sp.n. (from Colombia); A. mackameyi sp.n. (from Ecuador); A. onorei sp.n. (from Ecuador); A. schuhi sp.n. (from Peru).

KEY WORDS. Hemiptera, Membracidae, Membracinae, Hoplophorionini,
\end{abstract}

\section{Alchisme}

FAIRMAIRE (1846), ao descrever Triquetra, destacou que os úmeros eram longos e projetados em ponta. FOWLER (1894a) e BUCKTON (1903a) e FUNKHOUSER (1951) também assinalaram a importância deste caráter de indentificação. Em Hoplophorionini muitos gêneros possuem os ângulos umerais (aqui denominados processos ad-umerais) projetados além da base das tégminas. Em Alchisme, além de projetados, são acentuadamente voltados para frente e para cima, com as margens inferiores alcançando os olhos. Este último atributo é compartilhado apenas por parte das espécies acomodadas atualmente no gênero, e que compartilham ainda um outro caráter: tégminas com inúmeras veias transversais, irregulares.

1) Contribuição número 953 do Departamento de Zoologia, Universidade Federal do Paraná.

2) Departamento de Sistemática e Ecologia, Universidade Federal da Paraíba. 58059-900 João Pessoa, Paraíba, Brasil.

3) Departamento de Zoologia, Universidade Federal do Paraná. Caixa Postal 19020, 81531-990 Curitiba, Paraná, Brasil. Bolsista do CNPq. 
MCKAMEY \& DEITZ (1996) revisaram a tribo Hoplophorionini, a nível de gênero, acrescentando novos dados sobre a biologia de algumas espécies e também um estudo cladístico do grupo.

Aproveitamos para agredecer às seguintes instituições que enviaram material por empréstimo: AMNH - American Museum of Natural History, Estados Unidos; BMNH - The Natural History Museum, Inglaterra; DZUP - Departamento de Zoologia-UFPR, Brasil; INBIO - Instituto Nacional de Biodiversidad, Costa Rica; MRSN - Museo Regionale de Scienze Naturali, Itália; MZSP - Museu de Zoologia-USP, Brasil; NCSU -North Carolina State University, Estados Unidos; NHRS -Naturhistoriska Ricksmusset, Dinamarca; ZMUH - Universität Hamburg und Zoologisches Museum, Alemanha.

Em especial também, os agradecimentos a L.L. Deitz, S.H. McKamey, M. Webb, J. Margerison-Knight, T.J. Henry, C. Bordón, Pier L. Scaramozzino, Randall Schuh e Carolina Godoy.

\section{Alchisme Kirkaldy, 1904}

Triquetra Fairmaire, 1846: 279 (Espécie-tipo: Triquetra inermis Fairmaire, 1846, desig. subseq./indic., Funkhouser, 1927). (preoc.)

Alchisme Kirkaldy, 1904:279 (nom.n. pro Triquetra Fairmaire, 1846 nec Blainville, 1828). Funkhouser, 1927: 76. - Metcalf \& Wade, 1965: 555. - Deitz, 1975: 43. - Restrepo-Mejia, 1980: 103. - McKamey \& Deitz, 1996: 311.

Descrição. Colorido geral amarelado, castanho-amarelado ou castanho-escuro; em algumas espécies o macho castanho-escuro e a fêmea amarelada. Pronoto com o metopídio manchado ou não; carena mediana preta, avemelhada ou concolorida. Tégminas amareladas ou acastanhadas.

Cabeça sub-triangular ou triangular, tão larga quanto a base do processo posterior. Olhos elípticos ou globulares. Ocelos equidistantes ou ligeiramente aproximados entre si que dos olhos e situados na altura da linha imaginária que passa pelo centro dos olhos. Pós-clípeo, em vista lateral, globoso, sem intumescências laterais ou, quando presentes, adjacentes às margens internas dos lóbulos supra-antenais.

Pronoto com pontuação grosseira; dorsalmente convexo, em geral tectiforme, elevado, com processo anterior ou dorsal. Metopídio plano ou convexo. Processos ad-umerais bem desenvolvidos, delgados ou robustos, voltados para frente e para os lados, para cima ou para baixo; as margens inferiores alcançando ou não os olhos.

Tarsos I e II bem desenvolvidos, em geral com dois terços do comprimento das tíbias ou um pouco menores. Coxas II com ou sem espinho basal. Pernas III com número reduzido de setas cuculadas nas fileiras I e II.

Tégminas lanceoladas, de três a quatro vezes mais longas que largas, corrugadas entre as veias, pontuadas na metade proximal, entre as veias Costa e Sector e na base do clavo; veias bem definidas; cinco células apicais; transversa $\mathbf{s}$ presente, fechando a célula discoidal $\mathbf{S} 2$; transversa $\mathbf{s}-\mathbf{m}$ presente; duas transversas $\mathbf{m}$-cu fechando a célula discoidal M2+3. Asas com quatro células apicais; lóbulo jugal quase tão largo quanto longo. 
Abdome geralmente achatado dorso-ventralmente; pigóforo do macho com ou sem lóbulos laterais.

Comentários. Os processos ad-umerais em Alchisme são, em geral, bem desenvolvidos e o exame desta estrutura indica que o gênero pode ser dividido em dois grupos. No primeiro grupo, onde se inclui a espécie-tipo, os processos ad-umerais tem a margem inferior alcançando os olhos e, no segundo grupo, a margem inferior não alcança os olhos. Considerando então, que nem todas as espécies acomodadas no gênero portam os processos ad-umerais tal como na espécie-tipo, pensou-se, em princípio, reunir estas espécies em um novo gênero. Contudo, os estudos da morfologia não revelaram um caráter exclusivo sob o qual as espécies do segundo grupo pudessem ser reunidas. $\mathrm{O}$ fato da margem inferior dos processos ad-umerais não alcançar os olhos, no segundo grupo, não foi considerado um caráter exclusivo já que está presente em outros gêneros de Hoplophorionini que também tem processos ad-umerais.

MCKAMEY \& DEITZ (1996) acrescentaram caracteres de ninfas e também de biologia e comportamento de algumas espécies.

\section{Chave para espécies de Alchisme *}

*. Exceto para as espécies A. truncaticornis (Germar, 1835) e A. intermedia (Distant, 1881) que não foram vistas.

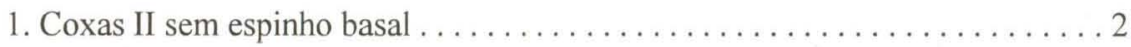

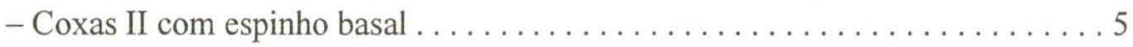

2. Margens inferiores dos processos ad-umerais alcançando os olhos ..... insolita

- Margens inferiores dos processos ad-umerais não alcançando os olhos . . . . . 3

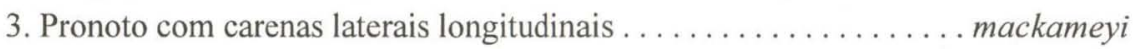

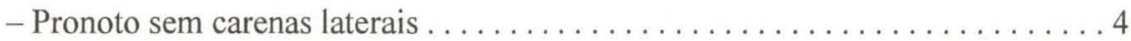

4. Processo dorsal escuro; carenas vermelhas . . . . . . . . . . . . . laticornis

- Processo dorsal claro; carenas amareladas . . . . . . . . . . . pinguicornis

5. Margens inferiores dos processos ad-umerais alcançando os olhos; tégminas com veias transversas irregulares $\ldots \ldots \ldots \ldots \ldots \ldots \ldots \ldots \ldots \ldots$

- Margens inferiores dos processos ad-umerais não alcançando os olhos; tégminas sem veias transversas . . . . . . . . . . . . . . . . . . 24

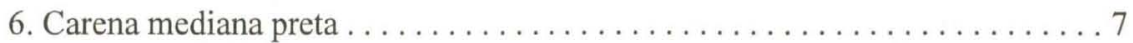

- Carena mediana de outra cor (se preta, apenas nos machos) . . . . . . . . 11

7. Pronoto convexo ou com discreta angulosidade ............... inermis

- Pronoto elevado, com processo anterior ou dorsal ................ 8

8. Pronoto apenas elevado anteriormente, em vista lateral triangular, com a parte mais elevada situada acima dos úmeros .................. onorei

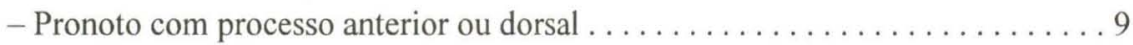

9. Pronoto com processo anterior curto, voltado para frente.......... tridentata

- Pronoto com processo dorsal $\ldots \ldots \ldots \ldots \ldots \ldots \ldots \ldots \ldots \ldots \ldots \ldots$ 
10. Processo dorsal voltado para cima $\ldots \ldots \ldots \ldots \ldots \ldots \ldots \ldots \ldots$ erecta

- Processo dorsal voltado para trás .................... recurva

11. Tégminas com uma mancha escura no clavo. Machos com pronoto elevado; abdome preto. Fêmeas com processo dorsal; abdome com mancha escura no quarto tergito e na placa subgenital . . . . . . . . . . . . . . fastidiosa

- Sem essas combinações de caracteres . . . . . . . . . . . . . . . . . 12

12. Edeago com seis espinhos subapicais, bem desenvolvidos . . . . . . . . 13

- Edeago com inúmeros espinhos subapicais, em geral diminutos . . . . . . . 15

13. Pronoto anguloso dorsalmente, com a parte mais elevada situada atrás dos úmeros; processos ad-umerais bem desenvolvidos, voltados para frente e com o ápice dirigido para cima ....................... bos

- Pronoto convexo dorsalmente; processos ad-umerais obtusos e voltados para frente .............................. 14

14. Edeago com o ápice sinuoso, voltado para cima ........... banosiensis

- Edeago com ápice não sinuoso, ligeiramente voltado para trás ......... bordoni

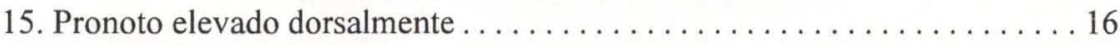

- Pronoto convexo dorsalmente . . . . . . . . . . . . . . . . . . . . 21

16. Ápice da elevação obtuso ou agudo, semelhante a um processo . . . . . . 17

- Ápice da elevação arredondado ou subanguloso . . . . . . . . . . . . . . . 19

17. Ápice da elevação dorsal obtuso . . . . . . . . . . . . . . . .

- Ápice da elevação dorsal agudo, semelhante a um processo . . . . . . . . 18

18. Elevação dorsal vertical. Nos machos a carena mediana pode ser preta, assim como a área adjacente. Edeago ligeriamente defletido para trás . . ustulata

- Elevação dorsal com ápice voltado para trás. Edeago fortemente defletido para trás .................................. virescens

19. Carena mediana avermelhada ....................... 20

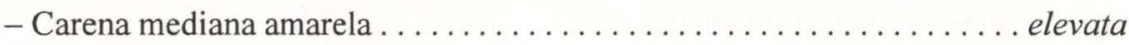

20. Elevação dorsal subangulosa, com ápice ligeiramente voltado para frente .... grossa

- Elevação dorsal arredondada ........................... salta

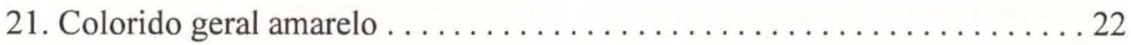

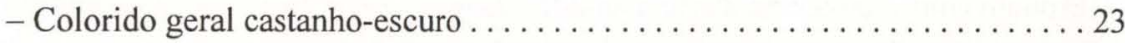

22. Carena mediana e processos ad-umerais avermelhados. Edeago com inúmeros espinhos subapicais bem definidos, dispersos pela superfície interna ...... rubrocostata

- Carena mediana e processos ad-umerais amarelados. Edeago com espinhos subapicais diminutos, quase imperceptíveis, em semicírculo, na superfície

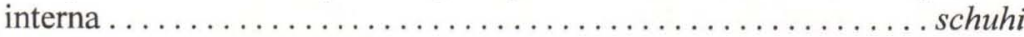


23. Edeago voltado para cima, com espinhos diminutos subapicais, dispostos em semicírculo ............................... henryi

- Edeago fortemente defletido para trás ...................... deflexa

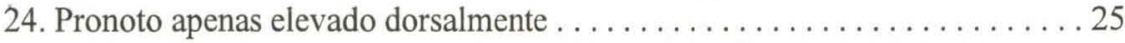

- Pronoto com processo dorsal distinto . . . . . . . . . . . . . . . . 27

25. Metopídio com uma mancha escura em $\mathrm{V}$ invertido ............. 26

- Metopídio sem mancha ............................... testacea

26. Mancha do metopídio estendendo-se até a extremidade dos processos ad-umerais colombiana

- Mancha do metopídio estendendo-se até as impressões musculares .

frontomaculata

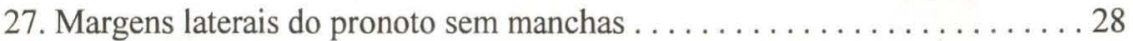

- Margens laterais do pronoto com uma ou duas manchas escuras . . . . . . . 29

28. Processos ad-umerais com uma mancha escura na face anterior ...... apicalis - Processos ad-umerais sem mancha na face anterior . . . . . . . . . obscura 29. Processo dorsal mais ou menos vertical; pronoto carenado lateralmente . . . 30 - Processo dorsal inclinado para frente; pronoto não carenado lateralmente . . . 31 30. Face anterior dos processos ad-umerais com uma grande mancha escura . . veruta - Face anterior dos processos ad-umerais sem mancha . ............ antigua 31. Processo dorsal com ápice truncado . ................... cultellata

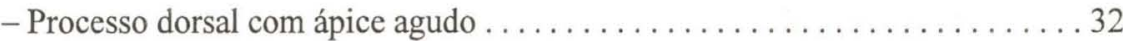
32. Processos ad-umerais delgados ...................... cultellata

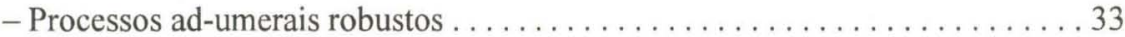
33. Processos ad-umerais mais ou menos longos, projetando-se à frente do metopídio . . . . . . . . . . . . . . . . . . . . . . . . . . turrita

- Processos ad-umerais curtos, não se projetando à frente do metopídio . . . goiana

As espécies descritas a seguir, são ordenadas conforme a saída na chave (exceto $A$. antigua).

\section{Alchisme insolita sp.n.}

Figs 1-3

Medidas. Fêmea. Comprimento do corpo 11,17; largura da cabeça 4,00; distância entre os processos ad-umerais 5,75.

Diagnose. Pronoto com carenas longitudinais laterais. Processo dorsal em forma de cifose, robusto, arredondado apicalmente, situado bem atrás dos úmeros, intumescido lateralmente; logo atrás do processo dorsal, uma outra pequena calosidade, levemente intumescida. Processos ad-umerais espatuladdos, voltados para os lados e acentuadamente para frente, com as margens inferiores alcançando os olhos. 


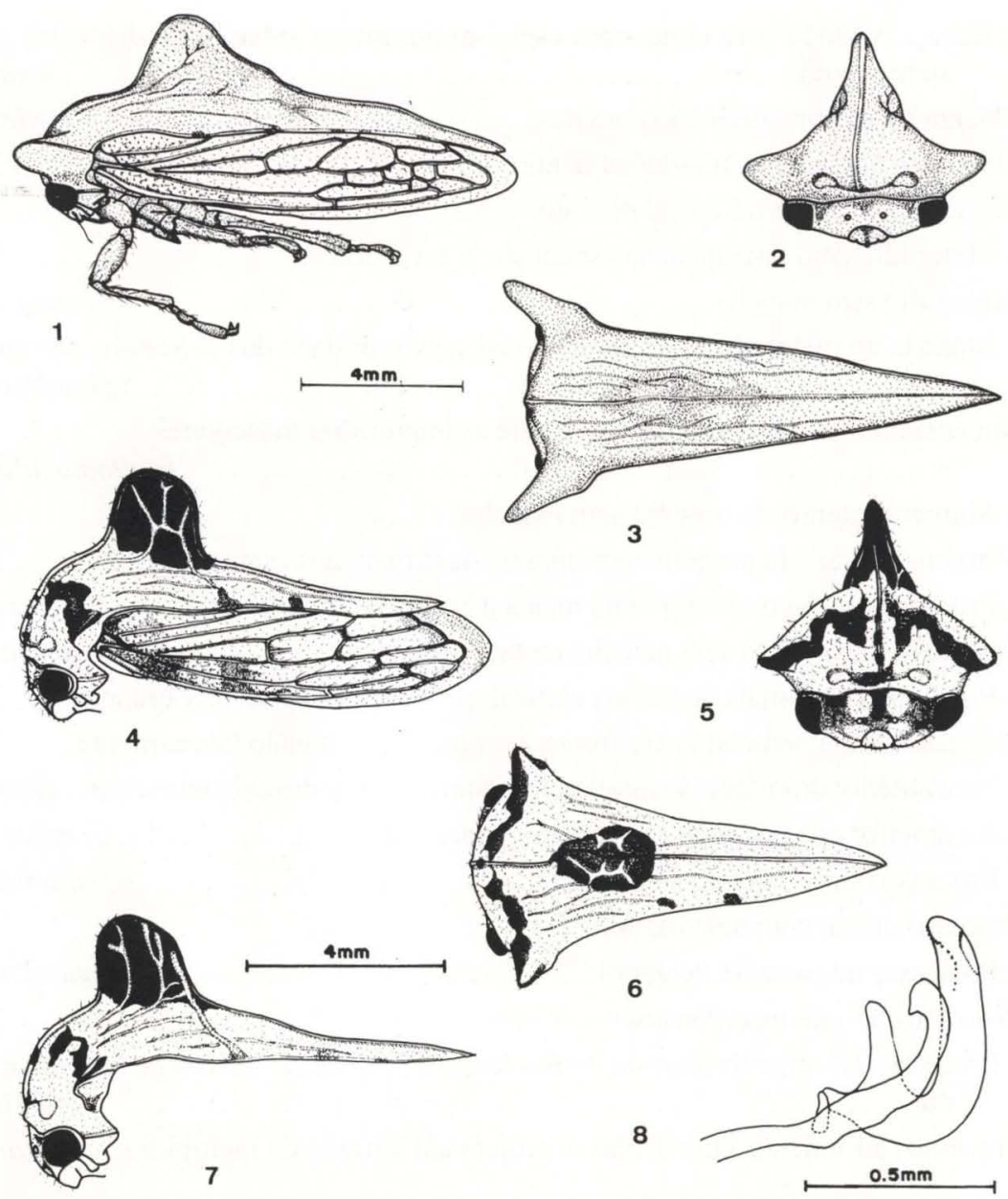

Figs 1-8. (1-3) Alchisme insolita sp.n., holótipo fêmea. (4-8) Alchisme mackameyi sp.n.: (4-6) fêmea, (7-8) holótipo macho.

Descrição. Holótipo fêmea. Colorido geral castanho-escuro; pós-clípeo com faixa escura longitudinal; tórax inferiormente e abdome, escuros; pernas castanhoescuras.

Cabeça subtriangular, três vezes mais larga que alta. Olhos globulares. Ocelos mais aproximados entre si do que dos olhos. Pós-clípeo piloso, carenado transversalmente. Lóbulos suprantenais não projetados para fora.

Pronoto com carenas longitudinais laterais; processo dorsal em forma de cifose, robusto, arredondado apicalmente e basalmente intumescido, situado bem atrás dos úmeros, mais ou menos no meio; logo a seguir, uma outra intumescência bem menor e discreta; metopídio convexo; processos ad-umerais espatulados, 
voltados para os lados e acentuadamente para frente, com as margens inferiores alcançando os olhos. Processo posterior acuminado, quase alcançando o ápice das tégminas.

Coxas II sem espinho basal; tíbias III sem setas cuculadas nas fileiras I e II; tarsos III reduzidos.

Tégminas com inúmeras veias transversais irregulares.

Macho. Desconhecido.

Material examinado. Holótipo fêmea. ColôMBIA: Cauca/P[arque] Nac[ional] Puracê (3.400m). 17.XII.1971, Bordón leg. (DZUP).

Comentários. Pela ausência do espinho basal da coxa II, a espécie se aproxima de A. laticornis, A. pinguicornis e A. mackameyi sp.n.

Etimologia. O nome da espécie é relativo a forma diferenciada do pronoto em comparação a das outras espécies.

\section{Alchisme mackameyi sp.n.}

Figs 4-8

Medidas. Fêmea/macho. Comprimento do corpo 9,42/8,17; largura da cabeça 3,33/3,00; distância entre os processos ad-umerais 4,50/4,17.

Diagnose. Pronoto com carenas longitudinais laterais; processo dorsal em forma de cifose, robusto, enegrecido e com carenas amarelas distintas, duas delas bem evidentes, situadas posteriormente, oblíquas, estendendo-se para as margens laterais. Metopídio com faixa sinuosa transversal alcançando os processos ad-umerais, preta.

Descrição. Holótipo macho. Colorido geral amarelo; cabeça enegrecida no meio e entre os olhos e ocelos; metopídio com faixa transversal preta; processo dorsal preto com carenas amarelas; processo posterior com duas pequenas manchas acastanhadas na margem; tórax e abdome inferiormente, escuros; pernas amarelas, coxas pretas; tégminas amareladas, com manchas escuras na margem costal e no clavo.

Cabeça subtriangular, três vezes mais larga que alta, pilosa. Olhos globulares. Ocelos mais aproximados entre si do que dos olhos, situados logo acima da linha imaginária que passa pelo centro dos olhos. Pós-clípeo piloso, com discretas intumescências laterais, adjacentes às margens internas dos lóbulos suprantenais e não projetados para fora.

Pronoto com carenas longitudinais laterais; grosseiramente pontuado; processo dorsal em forma de cifose, robusto e carenado; duas das carenas mais evidentes, oblíquas, estendendo-se para as margens laterais; processos ad-umerais desenvolvidos, robustos, voltados para frente e acentuadamente para os lados, com as margens inferiores não alcançando os olhos; processo posterior acuminado, alcançando o ápice da quarta célula apical das tégminas.

Pernas pilosas; coxas II sem espinho basal; tarsos III reduzidos.

Tégminas pilosas; venação normal, com veias bem definidas.

Pigóforo com placas laterais bem definidas; edeago em U. 
Fêmea. Maior, semelhante ao macho porém com o processo dorsal ligeiramente declinado para frente.

Material examinado. Holótipo macho. EQUADOR: Celica $(2.000 \mathrm{~m})$. 17.VIII.1977 (Luis Peña leg.) (UCMS). Parátipo: 1 fêmea com os mesmos dados do holótipo. (UCMS).

Comentários. Esta espécie aproxima-se de A. laticornis e A. pinguicornis. Difere delas pelas carenas laterais longitudinais do pronoto e pelos processos ad-umerais muito curtos.

Etimologia. A espécie é dedicada a Stuart H. McKamey.

\section{Alchisme laticornis Funkhouser, 1940}

Figs 9-11, 144

Alchisme laticornis Funkhouser, 1940: 277 (Loc.-tipo: Peru, Pumamarca). - Metcalf \& Wade, 1965: 559. - McKamey \& Deitz, 1996: 312.

Medidas. Macho. Comprimento do corpo 7,52; largura da cabeça 2,67; distância entre os processos ad-umerais 4,08 .

Diagnose. Processo dorsal em forma de cifose, robusto, preto e com carenas avermelhadas, anastomosadas; duas delas mais evidentes, situadas posteriormente, oblíquas, estendendo-se até às margens laterais. Metopídio com uma grande faixa transversal preta alcançando os processos ad-umerais.

Descrição. Macho. Colorido geral castanho-ferruginoso; cabeça inteiramente preta exceto duas manchas claras acima e abaixo dos ocelos; processo dorsal preto com carenas avermelhadas; metopídio com uma grande faixa transversal preta estendida até os processos ad-umerais e uma outra menor, entre as impressões musculares; processo posterior com uma pequena mancha acastanhada nas margens laterais; tórax inferiormente e abdome, pretos; pernas castanho-ferruginosas, exceto coxas, pretas; tégminas acastanhadas.

Cabeça subtriangular, três vezes mais larga que alta, pilosa. Olhos globulares. Ocelos mais aproximados entre si do que dos olhos, situados logo acima da linha imaginária que passa pelo centro dos olhos. Pós-clípeo globoso. Lóbulos suprantenais não projetados para frente.

Pronoto grosseiramente pontuado; processo dorsal em forma de cifose, bem desenvolvido, robusto, situado atrás dos úmeros, com carenas anastomosadas sendo que duas delas mais evidentes, situadas posteriormente, oblíquas, estendidas até às margens laterais. Processos ad-umerais bem desenvolvidos, robustos, voltados para frente e para os lados; margens inferiores não alcançando os olhos. Processo posterior acuminado atingindo o ápice da quinta célula apical das tégminas.

Coxas II sem espinho basal; tíbias III com número reduzido de setas cuculadas nas fileiras I e II; tarsos III reduzidos.

Tégminas com venação normal, veias bem definidas.

Fêmea. Desconhecida.

Material examinado. Holótipo macho. PerU: Pumamarca, 1872 (K. Jelski leg.) (USNM). 
Comentários. Esta espécie é muito parecida com A. mackameyi sp.n. diferindo na coloração, que é mais escura, e pela forma dos processos ad-umerais mais desenvolvidos.

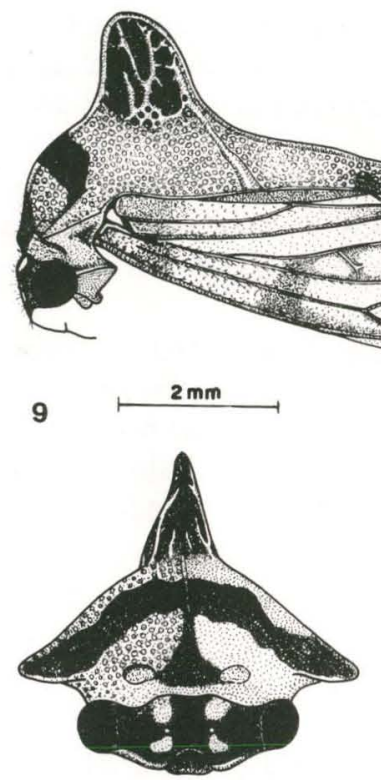

11

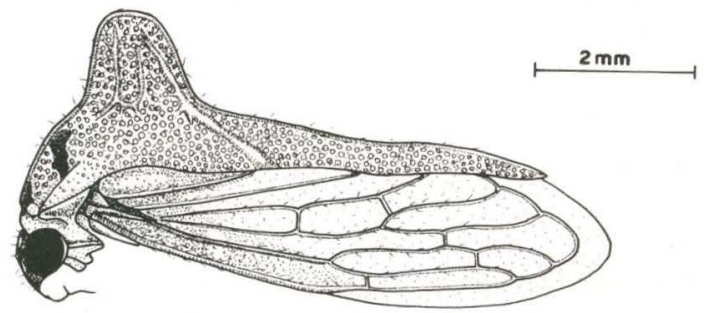

12
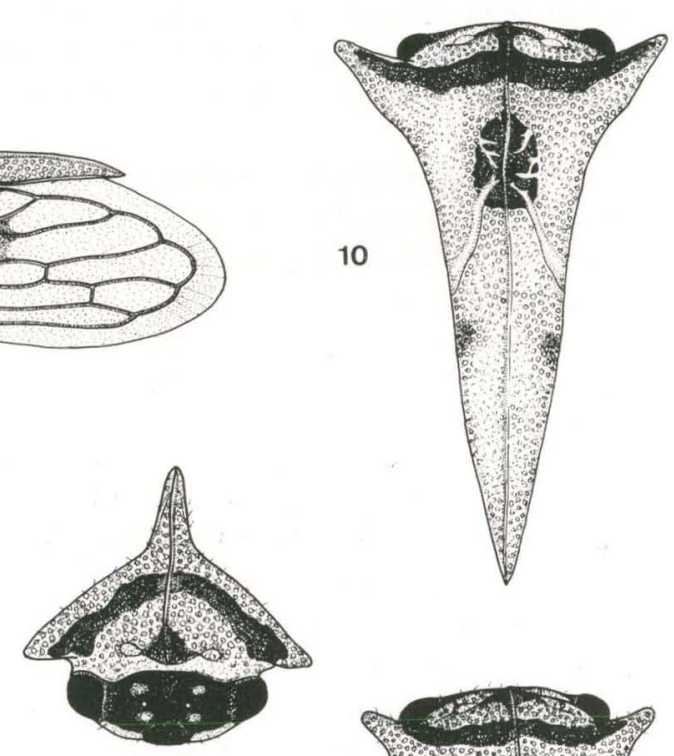

13

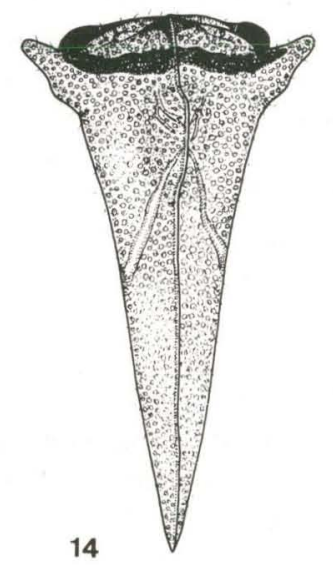

Figs 9-14. (9-11) Alchisme laticornis, macho. (12-14) Alchisme pinguicornis, holótipo macho.

\section{Alchisme pinguicornis Funkhouser, 1940 \\ Figs $12-14,145$}

Alchisme pinguicornis Funkhouser, 1940: 277 (Loc.-tipo: Peru, Santo Domingo). - Metcalf \& Wade, 1965: 560. - McKamey \& Deitz, 1996: 313.

Medidas. Macho. Comprimento do corpo 6,92; largura da cabeça 2,50; distância entre os processos ad-umerais 3,50. 
Diagnose. Processo dorsal em forma de cifose, robusto, com carenas distintas. Metopídio com faixa transversal preta estendida até os processos ad-umerais.

Descrição. Macho. Colorido geral acastanhado; cabeça inteiramente preta, exceto pequena mancha clara acima e abaixo dos ocelos; metopídio com uma faixa transversal preta atingindo os processos ad-umerais, e uma outra menor, entre as impressões musculares; processo posterior com uma pequena mancha lateral junto às margens; tórax inferiormente, coxas e abdome, pretos; pernas e tégminas acastanhadas.

Cabeça subtriangular, três vezes mais larga que alta, pilosa. Olhos globulares. Ocelos mais aproximados entre si do que dos olhos, situados logo acima da linha imaginária que passa pelo centro dos olhos. Pós-clípeo globoso. Lóbulos suprantenais não projetados para fora.

Pronoto grosseiramente pontuado; processo dorsal em forma de cifose, robusto, com carenas distintas, sendo duas delas mais evidentes, situadas posteriormente, oblíquas, atingindo as margens laterais; processos ad-umerais bem desenvolvidos, robustos, voltados para frente e acentuadamente para os lados, com as margens inferiores não alcançando os olhos; processo posterior acuminado atingindo o ápice da quarta célula apical das tégminas.

Coxas II sem espinho basal; tarsos III reduzidos.

Tégminas com venação normal, veias bem definidas.

Pigóforo com placas laterais bem definidas.

Fêmea. Desconhecida.

Material examinado. Holótipo macho. PERU: Santo Domingo, XI.1931. (USNM).

Comentários. A espécie aproxima-se de A. laticornis diferindo, basicamente, pelo processo dorsal vertical e destituido de manchas escuras.

\section{Alchisme inermis (Fairmaire, 1846)}

Figs 15-19

Triquetra inermis Fairmaire, 1846: 280 (Loc. tipo: Colômbia, Bogotá).

Microschema inermis; Buckton, 1901: 93

Microschema mucronata Buckton, 1905: 330 (Loc. tipo: desconhecida). - Funkhouser, 1927: 77. McKamey \& Deitz, 1996: 313.

Alchisme inermis; Funkhouser, 1927: 77. - Metcalf \& Wade, 1965: 559. - Restrepo-Mejia, 1980: 128. - McKamey \& Deitz, 1996: 312.

Triquetra nigrocarinata Fairmaire, 1846: 280 (Loc. tipo: Colômbia, Bogotá).

Alchisme nigrocarinata; Funkhouser, 1927: 78. - Metcalf \& Wade, 1965: 559. - McKamey \& Deitz, 1996: 312. Syn.n.

Medidas. Fêmea. Comprimento do corpo 12,83; largura da cabeça 3,83; distância entre os processos ad-umerais 7,50.

Diagnose. Pronoto convexo; carena mediana preta; processos ad-umerais longos, delgados, voltados para frente, para cima e para os lados.

Descrição. Fêmea. Colorido geral amarelo; carena mediana preta; tégminas amareladas. 


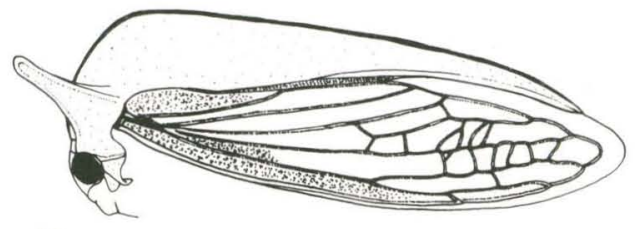

15
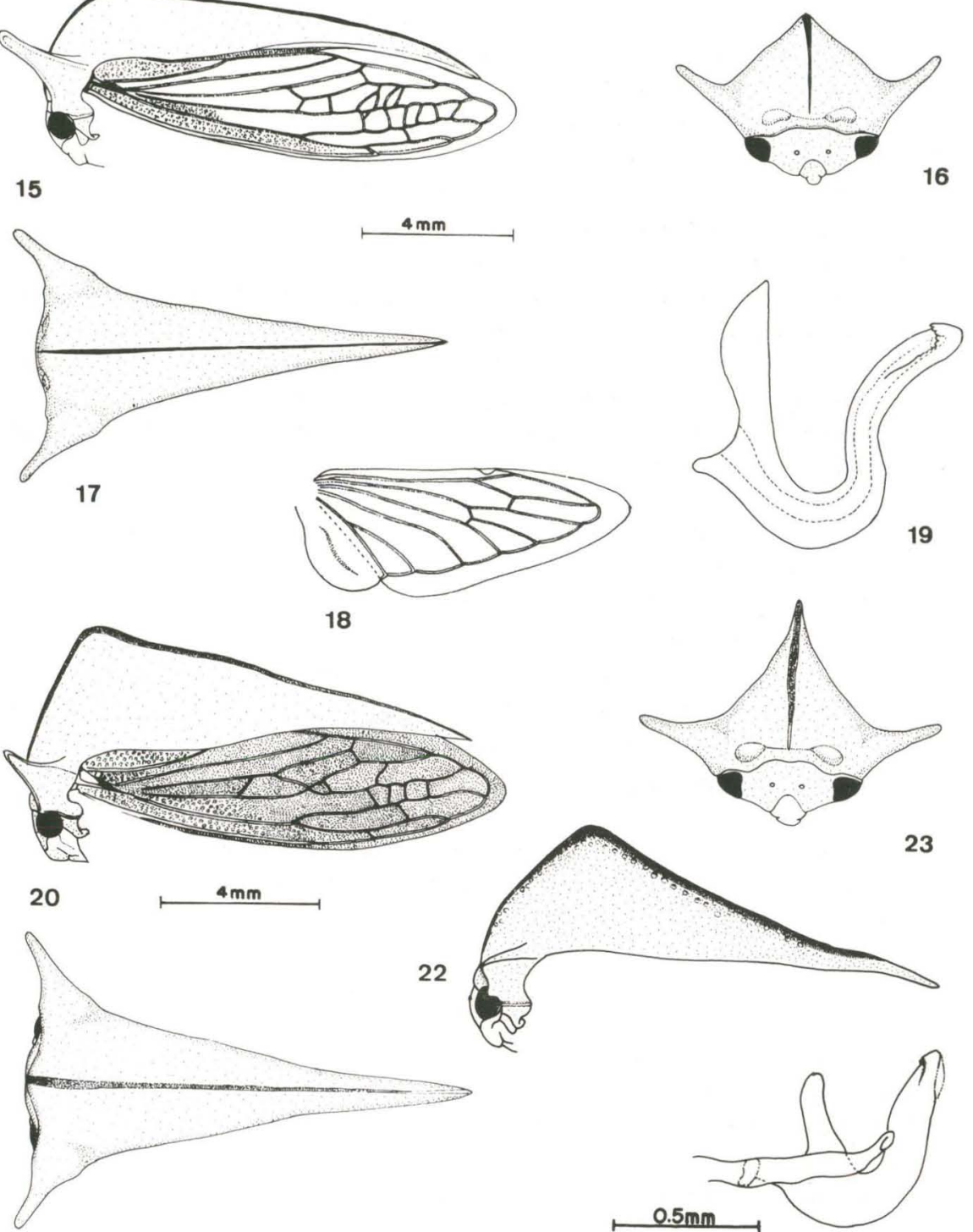

21

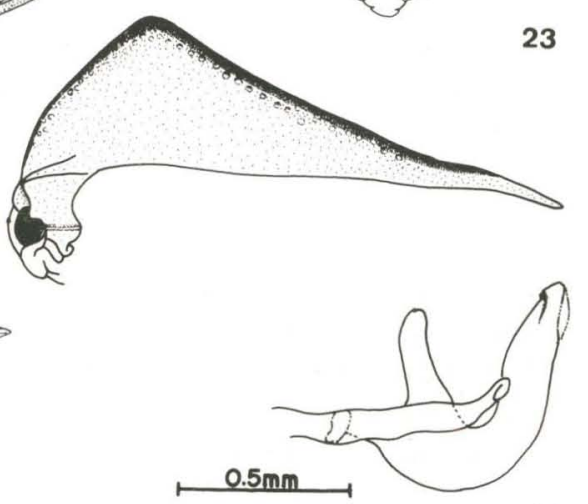

Figs 15-24. (15-19) Alchisme inermis. (15-18) Fêmea; (19) macho (segundo Restrepo-Mejia, 1980). (20-24) Alchisme onorei sp.n.: $(20,21,23)$ fêmea; $(22,24)$ macho.

Cabeça triangular, bem definida. Olhos elípticos. Ocelos ligeiramente mais aproximados entre si do que dos olhos, situados logo abaixo da linha imaginária qua passa pelo centro dos olhos. Pós-clípeo sem intumescências laterais. Lóbulos suprantenais não projetados. 
Pronoto convexo. Metopídio sem manchas. Carena mediana percurrente. Processos ad-umerais bem desenvolvidos, delgados, voltados acentuadamente para frente e para cima; margens inferiores alcançando os olhos.

Coxas II com espinho basal; tíbias III sem setas cuculadas nas fileiras I e II; tarsos III reduzidos.

Tégminas com veias transversais irregulares.

Abdome comprimido lateralmente.

Macho. Semelhante à fêmea, apresentando também as variações no pronoto.

Material examinado (só localidades). ColôMBIA: alto Rio Opon/Velez Borrasco; Anolaima (1.820m); Arcabuco, Boyaca (2.500m); Bogotá/Subpara$\mathrm{mo} /$ paramo (2.600-3.000m); Carretera Mesitas del Colegio (1.800m); Cundinamarca/Guasca-Gacheta $(1.900 \mathrm{~m})$; Rio Choco $(1800 \mathrm{~m})$; el Retiro; Fusagasugá; Guasca/Rio Sueva; Sibate/Aguadita. EQUADOR: Napo (5 Km de Baeza, 1900m) (USNM; ZMUH).

Lectótipo fêmea, aqui designado: "Colombie, D. Buquet / Hemipticha nigrocarinata var. mihi, Triquetra inermis, L. Fairm." (MRSN). Paralectótipos, 2 fêmeas: "Hemipticha nigrocarinata var. mihi / Triquetra inermis, L. Fairm." (MRSN).

O material estudado por Fairmaire pertencia às coleções Signoret, Guérin e Spinola. Apenas os exemplares da coleção Spinola (MRSN) foram obtidos.

Comentários. FAIRMAIRE (1846a), ao descrever Triquetra nigrocarinata, destacou a grande semelhança com $T$. inermis da qual diferenciava somente por um diminuto corno do pronoto.

Examinando os exemplares da coleção Spinola (MRSN), observou-se na etiqueta: "Hemipticha nigrocarinata var. mihi", que dá a entender que Spinola tinha os exemplares de $T$. nigrocarinata como variedade de $T$. inermis.

RESTREPO-MEJIA ((1980) afirmou que A. inermis e A. nigrocarinata podiam ser facilmente separadas pelo exame da genitália dos machos. Mas Restrepo-Mejia identificou erroneamente, chamando de A. nigrocarinata o que seria A. intermedia, decorrendo daí a diferença que ele se referiu.

Alchisme nigrocarinata passa a ser sinônimo de $A$. inermis. Essa conclusão decorreu do exame de 76 exemplares pertencente a ZMUH, coletados por Richter na Colômbia. Verificou-se, ao contrário do que afirmou Restrepo-Mejia, essas duas espécies apresentam a genitália semelhante. A forma do pronoto varia desde convexo anteriormente até em curto processo.

\section{Alchisme onorei sp.n.}

Figs 20-24

Medidas. Fêmea/macho. Comprimento do corpo 14,83/13,00; largura da cabeça 3,92/3,58; distância entre os processos ad-umerais 8,17/7,83.

Diagnose. Pronoto alaranjado, tectiforme, triangular em vista lateral, com a parte mais elevada situada acima dos úmeros; carena mediana preta; tégminas escuras. 
Descrição. Holótipo fêmea. Colorido geral alaranjado; carena mediana preta, exceto perto da cabeça e no terço apical do processo posterior; tégminas escuras.

Cabeça triangular, bem definida. Olhos elípticos. Ocelos ligeriamente aproximados entre si do que dos olhos, situados logo abaixo da linha imaginária que passa pelo centro dos olhos. Pós-clípeo ligeiramente piloso, sem intumescências laterais. Lóbulos suprantenais não projetados.

Pronoto tectiforme, triangular em vista lateral, com a parte mais elevada situada acima dos úmeros. Metopídio sem manchas. Processos ad-umerais bem desenvolvidos, delgados, ligeiramente voltados para frente, para cima e acentuadamente para os lados, quase paralelos à linha imaginária transversal que tangencia a cabeça; margens inferiores alcançando os olhos.

Coxas II com espinho basal; tíbias III sem setas cuculadas; tarsos III reduzidos.

Tégminas com veias transversais irregulares.

Abdome comprimido lateralmente.

Macho. Menor; pronoto com a parte mais elevada situada atrás dos úmeros; edeago em U, com espinhos diminutos subapicais, dispostos em semicírculo.

Material examinado. Holótipo macho. EQUADor:Cotopaxi/Las Pampas/"Amazonian Rainforest" (1.500m). IV.1982 (G. Onore leg.). (DZUP). Parátipos: ColômBIA:Fresno (2.200m), I.1952 (Richter leg.), 4 fêmeas e 3 machos. (ZMUH). EQUAdor: Las Pampas, VIII.1981 (G. Onore leg.), 1 fêmea. (DZUP).

Comentários. Esta espécie, além da carena mediana preta, apresenta o pronoto elevado anteriormente.

Etimologia. Espécie dedicada a G. Onore, do Equador, que cedeu alguns exemplares para estudo.

\section{Alchisme tridentata (Fairmaire, 1846)}

Figs 25-28

Triquetra tridentata Fairmaire, 1846: 280 (Loc. tipo: Colômbia, Bogotá). - Funkhouser, 1927: 77 (= Triquetra inermis) (error). -Metcalf \& Wade, 1965: 560 (=Alchisme nigrocarinata var. tridentata) (error).

Alchisme tridentata; Restrepo-Mejia, 1980: 139. - McKamey \& Deitz, 1996: 313.

Medidas. Fêmea. Comprimento do corpo 12,00; largura da cabeça 3,92; distância entre os processos ad-umerais 6,58.

Diagnose. Pronoto com processo anterior curto, voltado para frente; carena mediana preta; processos ad-umerais bem desenvolvidos, delgados, dirigidos para frente e para cima, em vista lateral mais ou menos no mesmo sentido que o processo anterior.

Descrição. Fêmea. Colorido geral amarelo; linha preta sobre a carena mediana, estendendo-se sobre a cabeça; tégminas amareladas.

Cabeça triangular, bem definida. Olhos elípticos. Ocelos ligeiramente mais aproximados entre si do que dos olhos, situados sobre a linha imaginária que passa pelo centro dos olhos. Pós-clípeo com pelos dispersos, sem intumescências laterais. Lóbulos suprantenais não projetados. 

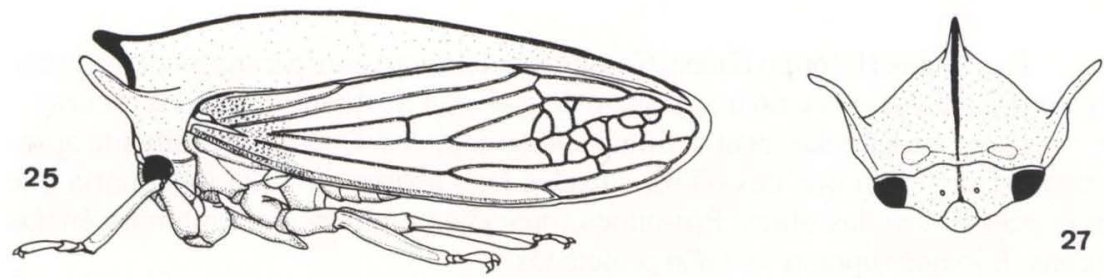

27

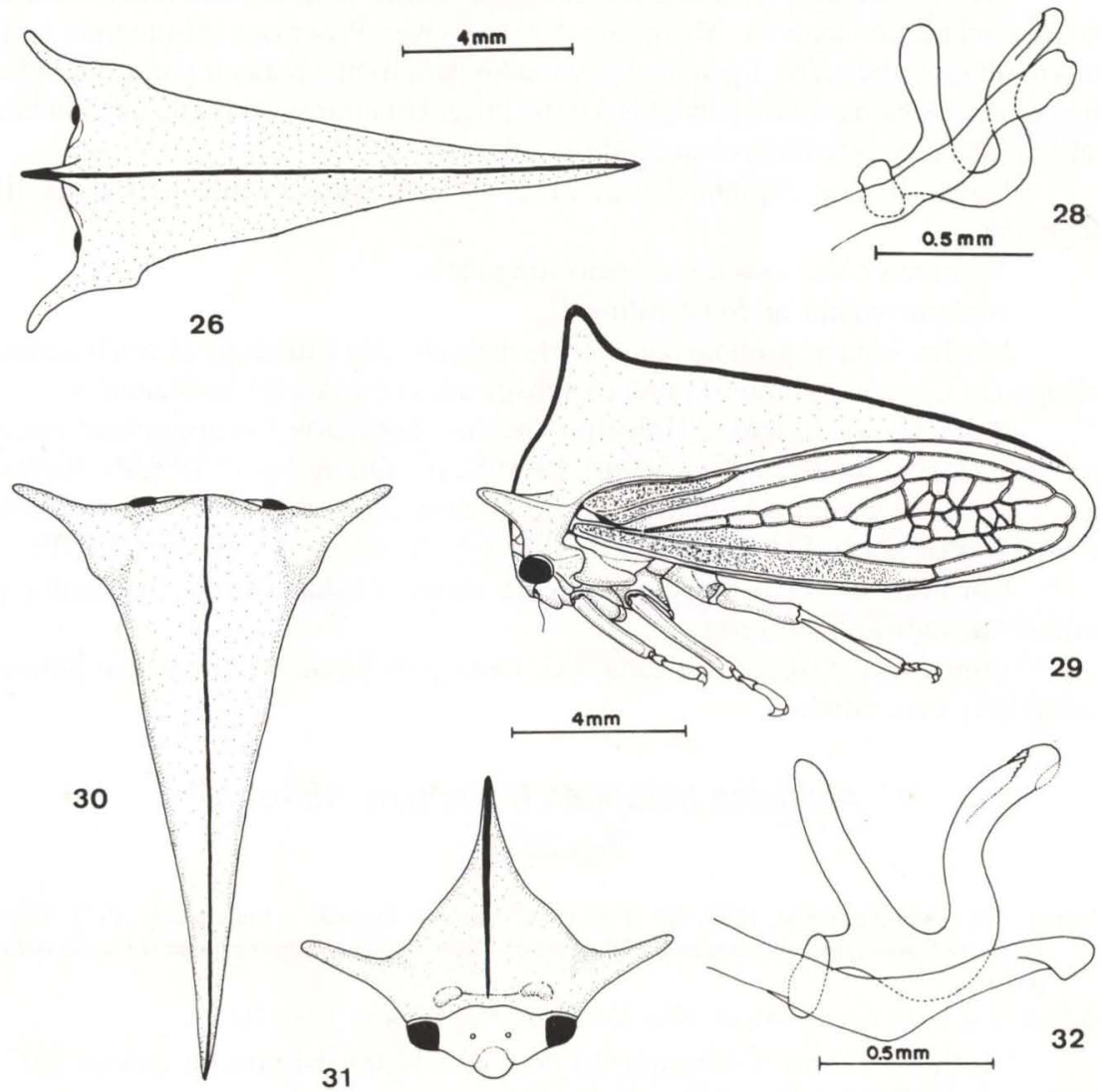

Figs 25-32. (25-28) Alchisme tridentata, macho. (29-32) Alchisme erecta sp.n., holótipo macho.

Pronoto tectiforme; processo anterior curto, voltado para frente. Metopídio com impressões musculares acentuadas. Processos ad-umerais bem desenvolvidos, delgados, voltados acentuadamente para frente e para cima; margens inferiores alcançando os olhos; em vista lateral mais ou menos no mesmo sentido que o processo anterior.

Coxas II com espinho basal; tíbias III sem setas cuculadas; tarsos III reduzidos. 
Tégminas com veias transversais irregulares.

Abdome comprimido lateralmente.

Macho. Menor; edeago defletido para trás, com espinhos diminutos subapicais, dispostos em semicírculo.

Material examinado (só localidades). CoLôMBIA: Antioquia/La Iguana (17 Km NW de Medelin). Equador: Cotopaxi/Latacunga (113 Km W); S. Domingo; Tungurahua/Baños (15 Km E). (DZUP; USNM).

Comentários. A espécie aproxima-se de $A$. erecta e de $A$. recurva, diferindo destas pelo processo anterior voltado para frente e paralelo aos processos ad-umerais.

\section{Alchisme erecta sp.n.}

Figs 29-32

Medidas. Fêmea/macho. Comprimento do corpo 13,33/12,17; largura da cabeça 4,00/3,75; distância entre os processos ad-umerais 9,50/8,17.

Diagnose. Carena mediana preta; processo dorsal curto, mais ou menos vertical.

Descrição. Holótipo macho. Colorido geral amarelo-acastanhado; carena mediana preta; tégminas amareladas.

Cabeça triangular, bem definida. Olhos elípticos. Ocelos mais aproximados entre si do que dos olhos, situados sobre a linha imaginária que passa pelo centro dos olhos. Pós-clípeo piloso, com discreta intumescência longitudinal mediana. Lóbulos suprantenais não projetados para fora.

Pronoto tectiforme; processo dorsal curto, mais ou menos vertical. Processos ad-umerais bem desenvolvidos, delgados, dirigidos para frente e para cima, mais acentuadamente para os lados; margens inferiores alcançando os olhos.

Tégminas com veias transversas irregulares.

Coxas II com espinho basal; tíbias III sem setas cuculadas nas fileira I e II; tarsos III reduzidos.

Abdome comprimido lateralmente; edeago curvado para trás, com espinhos diminutos aubapicais, dispostos em semicírculo.

Fêmea. Semelhante.

Material examinado. Holótipo macho. VENEZUELA: Trujillo/Boconó/Águas Negras (1.500m). 24.VII.1967 (Bordón leg.). (DZUP). Parátipos: VENEZUELA: Trujillo/Boconó/Águas Negras (1.500m). 24.VII.1967 (Bordón leg.), 2 fêmeas; Trujillo/Loma del Santuario (2.000m). 18.V.1980 (Bordón leg.), 1 macho. (DZUP).

Comentários. A espécie aproxima-se de A. recurva diferindo principalmente pelo processo dorsal que é voltado para cima e reto; o edeago dilatado no ápice e pouco mais inclinado para trás; os parâmeros tem a extremidade em forma de gancho, voltado para fora.

Etimologia. Relativo ao processo dorsal que é vertical. 


\section{Alchisme recurva (Stål, 1869)}

Figs 33-36, 146

Triquetra recurva Stål, 1869b: 266 (Loc. tipo: Colômbia, Bogotá).

Microschema recurva; Buckton, 1902: 102.

Alchisme recurva; Goding, 1929b: 206. - Metcalf \& Wade, 1965: 560. - Restrepo-Mejia, 1980: 135. McKamey \& Deitz, 1996: 313.

Medidas. Fêmea/macho. Comprimento do corpo 13,17/13,17; largura da cabeça 4,08/3,75; distância entre os processos ad-umerais 9,02/8,33.

Diagnose. Carena mediana preta; processo dorsal voltado para cima, curvado para trás e situado atrás dos úmeros.

Descrição. Fêmea. Colorido geral amarelo; sutura coronal preta; carena mediana preta; tégminas amareladas.

Cabeça triangular, bem definida. Olhos elípticos. Ocelos mais aproximados entre si do que dos olhos, situados na altura da linha imaginária que passa pelo centro dos olhos. Pós-clípeo piloso, com uma intumescência longitudinal mediana. Lóbulos suprantenais não projetados.

Pronoto tectiforme; processo dorsal voltado para cima e para trás, situado atrás dos úmeros. Metopídio sem manchas. Processos ad-umerais bem desenvolvidos, voltados para frente e acentuadamente para os lados e para cima; margens inferiores alcançando os olhos.

Coxas II com espinho basal; tíbias III sem setas cuculadas; tarsos III reduzidos.

Tégminas com veias transversais irregulares.

Abdome comprimido lateralmente.

Material examinado (só localidades). CoLÔMBIA: La Plata Huilo $(2.600 \mathrm{~m})$; Lubia (2.600m). (DZUP; ZMUH).

Apenas a fotografia (slide) do tipo foi examinada.

Comentários. A forma do processo dorsal pode variar; em alguns casos é bem desenvolvido e curvo; em outros, bem curto e pouco curvo.

\section{Alchisme fastidiosa (Fairmaire, 1846)}

Figs $37-41$

Triquetra fastidiosa Fairmaire, 1846: 281 (Loc. tipo: Colômbia).

Triquetra submaculata Buckton, 1901: 92 (Loc. tipo: Equador). -Metcalf \& Wade, 1965: 557 (syn.). McKamey \& Deitz, 1996: 312.

Triquetra angustata Fairmaire, 1846: 282 (Loc. tipo: Colômbia, Bogotá). - Metcalf \& Wade, 1965: 557. - McKamey \& Deitz, 1996: 312.

Alchisme angustata; Funkhouser, 1927: 76.

Ceresa fastidiosa; Funkhouser, 1927: 199.

Alchisme fastidiosa; Metcalf \& Wade, 1965: 557. - McKamey \& Deitz, 1996: 312.

Medidas. Fêmea/macho. Comprimento do corpo 10,33/10,50; largura da cabeça 3,50/3,33; distância entre os processos ad-umerais 6,42/6,00.

Diagnose. Colorido geral castanho. Tégminas com mancha escura no clavo junto à margem externa. 

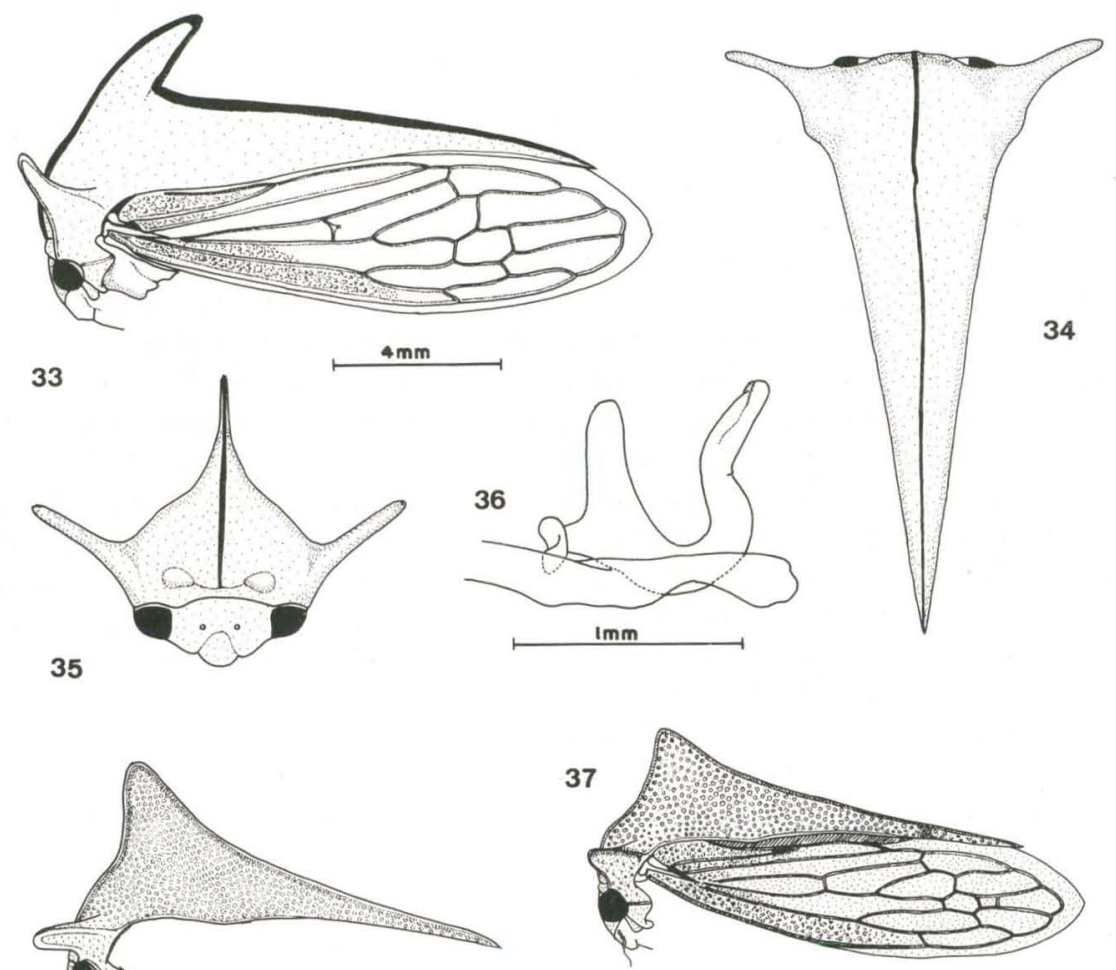

38

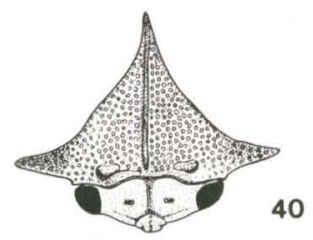

39

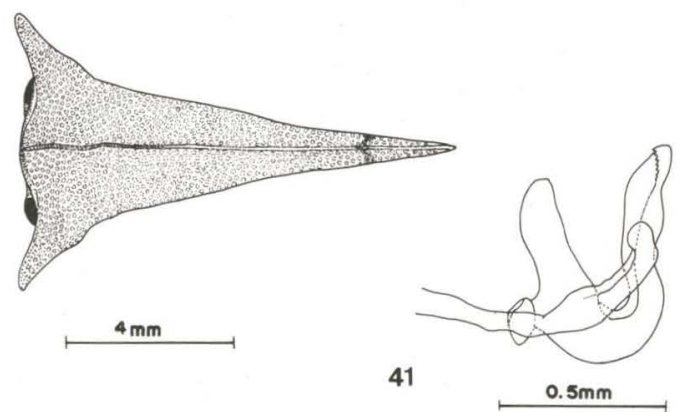

Figs 33-41. (33-36) Alchisme recurva, macho. (37-41) Alchisme fastidiosa: (37) fêmea, (38-41) macho.

Descrição. Macho. Colorido geral acastanhado; processo posterior com duas pequenas manchas escuras perto do ápice; tégminas escurecidas; abdome preto.

Cabeça triangular, bem definida. Olhos elípticos. Ocelos equidistantes entre si e dos olhos, situados logo abaixo da linha imaginária que passa pelo centro dos olhos. Pós-clípeo com discreta carena mediana; sem intumescências laterais. Lóbulos suprantenais não projetados.

Pronoto elevado, tectiforme, em vista lateral triangular, com a parte mais elevada situada acima dos úmeros. Processos ad-umerais bem desenvolvidos, 
dirigidos para frente e para cima, mais acentuadamente para os lados; margens inferiores alcançando os olhos.

Coxas II com espinho basal; tíbias III sem setas cuculadas nas fileiras I e II; tarsos III reduzidos.

Tégminas com veias bem definidas, em geral com venação normal.

Edeago em U com pequenos espinhos subapicais dispostos em semicírculo.

Fêmea. Coloração geral amarela, com mancha escura no quarto tergito abdominal e na placa subgenital. Pronoto com elevação dorsal discreta.

Material examinado (só localidades). CoLÔMBIA: Anolaima/Facatativa; Bogotá/Chiro; Bogotá/Parque Nac[ional]; Cahipay (1.620m); Cundinamarca/GuascaGacheta (1.800-3.200m); Guasca/Rio Sueva; San Miguel $(2.900 \mathrm{~m})$; Q. Tasajera $(2.000 \mathrm{~m})$; Subparamo/el Chico $(3.000 \mathrm{~m})$; Subparamo/Usaquen; Tequedama $(2.400 \mathrm{~m})$. VenEZUELA: Lara/P.[arque] Nac.[ional] Yacambú $(1.500 \mathrm{~m}) ;$ Merida (10 Km E de Tabay-2.300m); Merida/Carbonera (2.300m); Merida/La Mucuy $(2.300 \mathrm{~m})$; Merida/Timotes $(2.200 \mathrm{~m})$; Merida/Portachuelo $(3.300 \mathrm{~m})$; Trujillo/Boconó $(2.500 \mathrm{~m})$; P[ara]mo de Guaramacal $(2.500 \mathrm{~m})$; Trujillo/Bovonó/Loma del Santuario (2.000m). (AMNH; DZUP; ZMUH; Coleção Bordón).

Lectótipo macho, aqui designado: "Colombie, D. Reiche / Hemiptycha fastidita (Triquetra), L. Fairm.”. (MRSN).

Comentários. O exemplar-tipo existente na coleção Spinola (MRSN) apresenta a etiqueta com o nome Hemiptycha fastidita. A descrição original de Triquetra fastidiosa Fairmaire corresponde perfeitamente, razão pela qual consideramos como sendo uma grafia incorreta por ocasião da etiquetagem.

A espécie se caracteriza pelo processo dorsal relativamente pequeno, obtuso, situado acima dos úmeros; a coloração geral e acastanhada a amarelada.

\section{Alchisme bos (Fairmaire, 1846)}

Figs $42-46$

Triquetra bos Fairmaire, 1846:28 (Loc. tipo: Colômbia, Bogotá).

Microschema obtusa Buckton, 1901: 92 (Loc. tipo:Colômbia). -McKamey \& Deitz, 1996: 312.

Triquetra obtusa; Buckton, 1901: 91.

Microschema bos; Buckton, 1901: 93.

Alchisme bos; Funkhouser, 1927: 76. - Metcalf \& Wade, 1965: 557. -Restrepo-Mejia, 1980: 118. McKamey \& Deitz, 1996: 312.

Alchisme projecta Funkhouser, 1930: 414 (Loc. tipo: Peru, Calanga). - Metcalf \& Wade, 1965: 560. Restrepo-Mejia, 1980: 118 (syn.). -McKamey \& Deitz, 1996: 312.

Medidas. Fêmea/macho. Comprimento do corpo 10,50/11,00; largura da cabeça 3,75/3,50; distância entre os processos ad-umerais 6,17/6,50.

Diagnose. Pronoto com a parte mais elevada situada atrás dos úmeros; processos ad-umerais bem desenvolvidos, voltados para frente e para cima.

Descrição. Fêmea. Colorido geral amarelo acastanhado; processos ad-umerais com ápices escurecidos; tégminas amareladas.

Cabeça triangular, bem definida. Olhos elípticos. Ocelos equidistantes entre si e dos olhos, situados abaixo da linha imaginária que passa pelo centro dos olhos. Pós-clípeo sem intumescências laterais. Lóbulos suprantenais não projetados. 

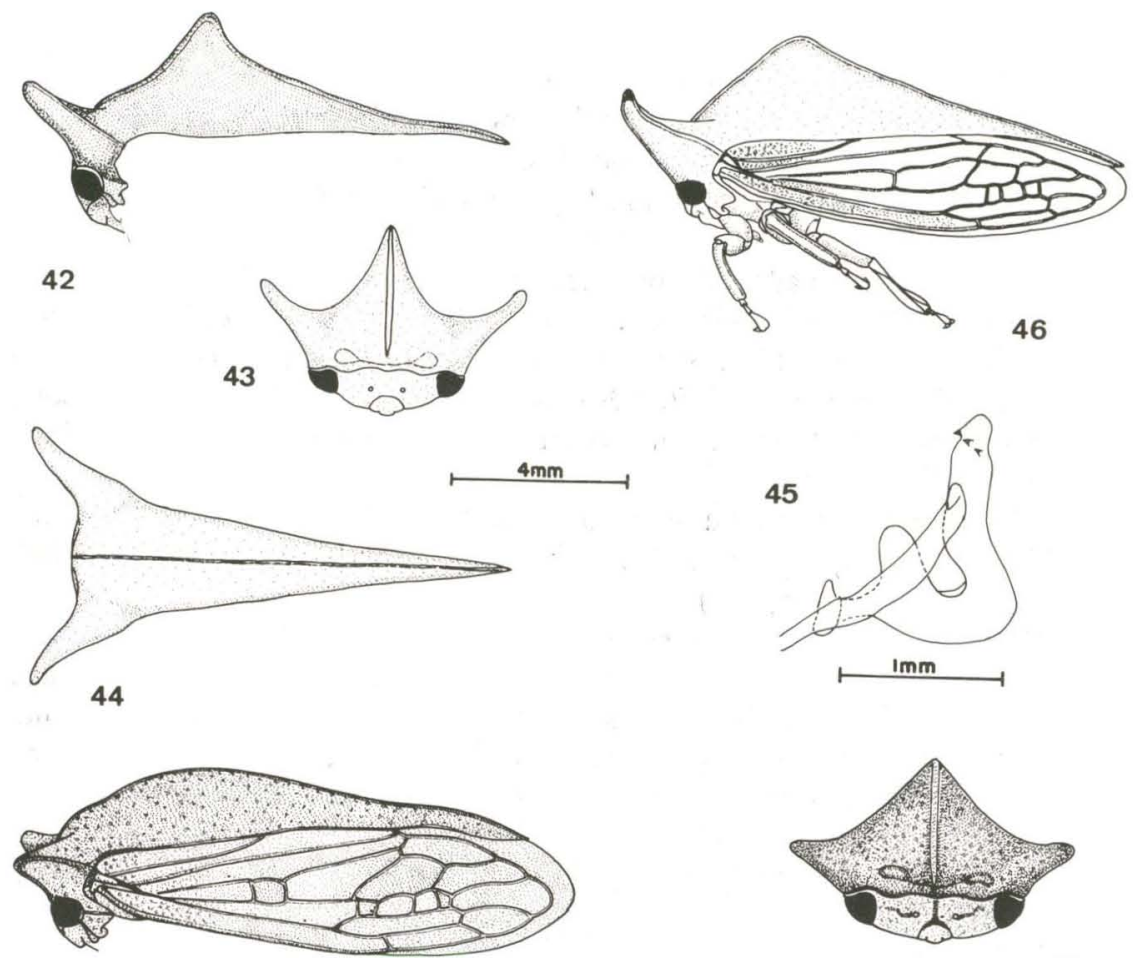

47

49
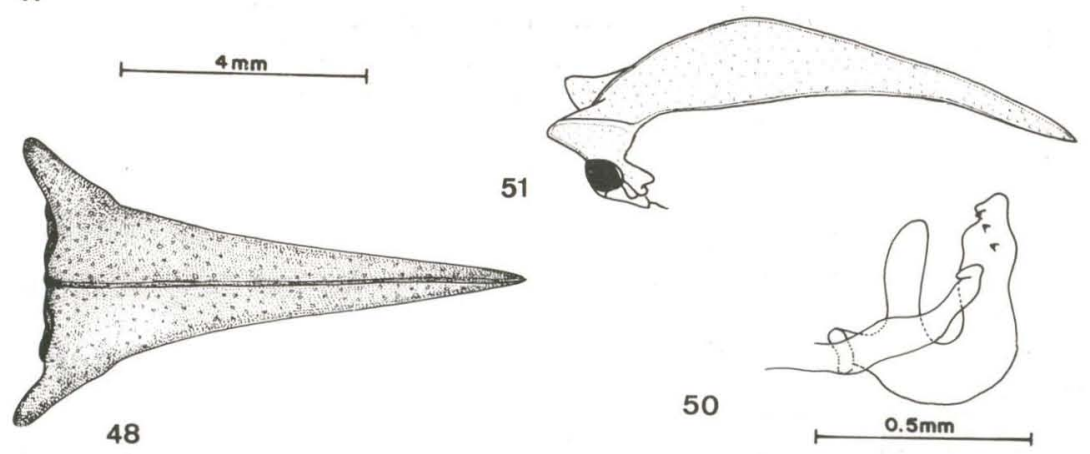

Figs 42-51. (42-46) Alchisme bos: (42-45) macho, (46) fêmea. (47-51) Alchisme banosiensis sp.n.: (47-50) holótipo macho, (51) fêmea.

Pronoto elevado, em vista lateral triangular, com a parte mais elevada angulosa e situada bem atrás dos úmeros; pontuação discreta e pequenas granulações dispersas na superfície. Processos ad-umerais bem desenvolvidos, voltados para os lados e acentuadamente para frente e para cima; ápices curvados; margens inferiores alcançando os olhos.

Coxas II com espinho basal; tíbias III sem setas cuculadas nas fileiras I e II; tarsos III reduzidos. 
Tégminas com veias transversais irregulares.

Abdome ligeiramente comprimido dorso-ventralmente; edeago em U, com seis espinhos subapicais bem desenvolvidos.

Macho. Coloração do pronoto e tégminas mais escura. Elevação dorsal mais aguda.

Material examinado (só localidades). ColôMBIA: Anolaima / Facativa; Bogotá; Bogotá/Parque Nacional; Bogotá/el Chico/Usaquen $(2.800 \mathrm{~m}) ;$ Bogotá/Subparamo; Cachipay (1.620m); Cundinamarca / Gasca-Gacheta (2.800m); Rio Guavio (2.400m); San Miguel (2.200-3.00m). EQUADOR: Baños (2.200m); Loja; mt. Tunguruhua $(2.800 \mathrm{~m})$; Paramo de Arango; Subparamo/El Chico $(3.000 \mathrm{~m})$. PERU: Callaiga.

Lectótipo fêmea, aqui designado: "Hemiptycha Bos (Triquetra) L. Fairm." (MRSN). Paralectótipo, fêmea: "Colombie, D. Buquet, 1843/ Hemiptycha Bos (Triquetra) L. Fairm.” (MRSN).

Holótipo macho de Alchisme projecta Funkhouser, 1930. (NCSU).

Comentários. Esta espécie apresenta o pronoto discretamente elevado atrás dos úmeros; os processos ad-umerais são bem desenvolvidos e voltados para frente e para cima, com os ápices ligeiramente curvados. A presença de seis espinhos subapicais no edeago também ocorre em A. singela e A. banosiensis.

\section{Alchisme banosiensis sp.n.}

Figs 47-50

Medidas. Fêmea/macho. Comprimento do corpo 8,08/8,42; largura da cabeça 3,08/2,83; distância entre os processos ad-umerais 4,25/4,42.

Diagnose. Pronoto convexo; edeago em $\mathrm{U}$, com seis espinhos subapicais bem desenvolvidos; ápice sinuoso.

Descrição. Holótipo macho. Colorido geral castanho-acinzentado; cabeça com manchas escuras junto dos ocelos e ao longo da linha mediana; tégminas escurecidas.

Cabeça triangular, bem definida, pilosa. Olhos elípticos. Ocelos ligeiramente mais aproximados entre si do que dos olhos, situados sobre a linha imaginária que passa pelo centro dos olhos. Pós-clípeo piloso, com duas discretas intumescências laterais, adjacentes às margens internas dos lóbulos suprantenais.

Pronoto convexo, baixo, grosseiramente pontuado. Processos ad-umerais voltados para frente e para os lados; margens inferiores alcançando os olhos.

Coxas II com espinho basal; tíbias III sem setas cuculadas nas fileiras I e II; tarsos III reduzidos.

Tégminas com veias transversais irregulares.

Abdome ligeiramente comprimido dorso-ventralmente. Edeago em U, com seis espinhos subapicais; ápice sinuoso.

Fêmea. Semelhante ao macho, apenas de coloração mais amarelada.

Material examinado. Holótipo macho. EQUADOR:Baños/Azuay (2.600m), 20.V.1986. McKamey (UCMS). Parátipos: 25 fêmeas e 6 machos, com os mesmos dados do holótipo (UCMS; DZUP). 
Comentários. A espécie aproxima-se de $A$. bordoni diferindo pelo pronoto menos elevado e pelo edeago voltado para cima e com o ápice sinuoso.

Etimologia. Alusivo à localidade-tipo.

\section{Alchisme bordoni sp.n.}

Figs $52-56$

Medidas. Fêmea/macho. Comprimento do corpo 9,17/10,33; largura da cabeça 3,25/3,42; distância entre os peocessos ad-umerais 4,67/5,83.

Diagnose. Pronoto convexo; processos ad-umerais com as margens inferiores alcançando os olhos; edeago com seis espinhos subapicais.

Descrição. Holótipo macho. Colorido geral castanho; carena mediana escurecida; tégminas escurecidas; abdome escuro.

Cabeça triangular, bem definida. Olhos elípticos. Ocelos ligeiramente mais aproximados entre si do que dos olhos, situados sobre a linha imaginária que passa pelo centro dos olhos. Pós-clípeo piloso, carenado longitudinalmente, sem intumescências laterais. Lóbulos suprantenais não projetados.

Pronoto grosseiramente pontuado, convexo, pouco elevado. Processos adumerais voltados para frente e para os lados; margens inferiores alcançando os olhos.

Coxas II com espinho basal; tíbias III sem setas cuculadas; tarsos III reduzidos.

Tégminas com veias transversais irregulares.

Abdome comprimido lateralmente. Edeago em U, com seis espinhos subapicais; ápice sinuoso, ligeiramente voltado para trás.

Fêmea. Semelhante ao macho, apenas de coloração mais amarelada.

Material examindado. Holótipo macho. Venezuela: Táchira/ Zumbador (2.600m), 12.I.1982, Bordón (DZUP).

Parátipos:VENEZUELA. 1 macho, Tachira/Zumbador (2.600m), 12.I.1982, Bordón. (DZUP); 1 macho, Mérida/Páramo la Culata (3.400m), 2.III.1978, Bordón; Mérida/Cacule (2.200m), 14.X.1981, Bordón; Mérida/Timotes $(2.200 \mathrm{~m})$, 23.I.1968, Bordón; Trujillo/Boconó (2.200m), 22.V.1980, Bordón (Coleção Bordón).

Comentários. O edeago com seis espinhos subapicais faz aproximá-la de $A$. banosiensis e de A. bos. Difere desta última pelo pronoto menos elevado.

Etimologia. Dedicada a C. Bordón, pelo empréstimo de material de sua coleção.

\section{Alchisme deflexa sp.n.}

Figs $57-61$

Medidas. Macho. Comprimento do corpo 10,50; largura da cabeça 3,42; distância entre os processos ad-umerais 5,83.

Diagnose. Pronoto convexo; edeago fortemente defletido para trás, com espinhos subapicais diminutos. 

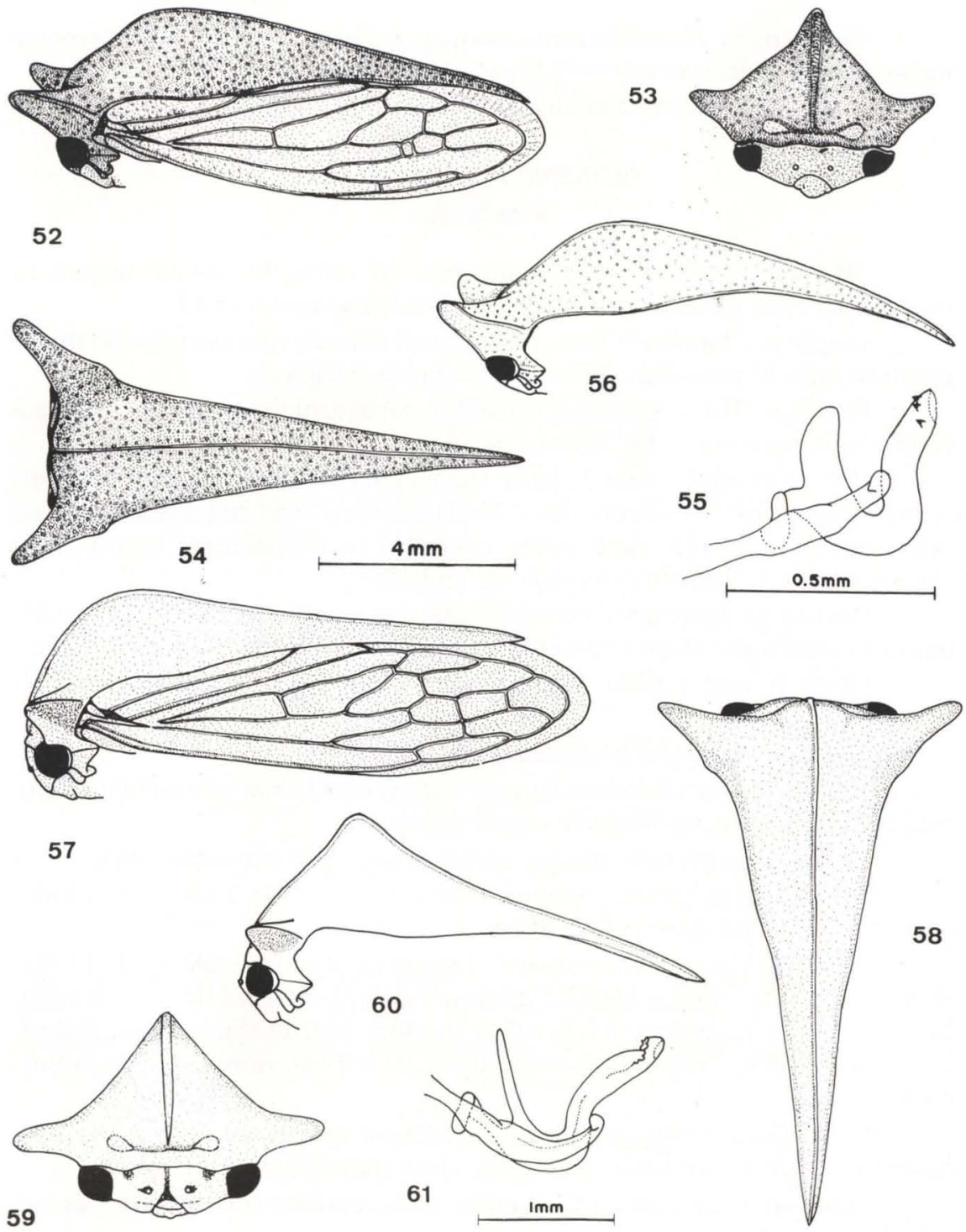

Figs 52-61. (52-56) Alchisme bordoni sp.n.: (52-55) holótipo macho, (56) fêmea. (57-61) Alchisme deflexa sp.n., macho.

Descrição. Holótipo macho. Colorido geral acastanhado; cabeça com manchas escuras nos lados dos ocelos; carena mediana avermelhada; processos ad-umerais com a face posterior escurecida; tégminas escurecidas.

Cabeça triangular, bem definida. Olhos elípticos. Ocelos ligeiramente mais aproximados entre si do que dos olhos, situados logo abaixo da linha imaginária que 
passa pelo centro dos olhos. Pós-clípeo com carena mediana. Lóbulos suprantenais não projetados para fora.

Pronoto convexo, pouco elevado. Processos ad-umerais desenvolvidos, voltados para os lados e levemente para frente; margens inferiores alcançando os olhos.

Coxas II com espinho basal; tíbias III sem setas cuculadas nas fileiras I e II; tarsos III reduzidos.

Tégminas com veias transversais irregulares.

Abdome ligeiramente comprimido dorso-ventralmente; edeago fortemente defletido para trás, com espinhos subapicais diminutos.

Fêmea. Desconhecida.

Material examinado. Holótipo macho. VENEZUELA: Mérida/

Zumbador (2.600m), 12.I.1982, Bordón. (DZUP). Parátipos:VENEZUELA. 1 macho, Mérida/Cacule (2.200m), 14.X.1981, Bordón; 1 macho, Mérida/Páramo la Culata $(3.400 \mathrm{~m}), 2 . I I I .1978$, Bordón; 1 macho, Tachira/Zumbador $(2.600 \mathrm{~m})$, 12.I.1982, Bordón; 1 macho, Trujillo/Boconó (2.200m), 22.V.1980, Bordón (Coleção Bordón).

Comentários. O pronoto pode apresentar-se convexo, pouco elevado, ou distintamente elevado e anguloso. A forma do edeago é bem característica com o ápice fortemente defletido para trás.

Etimologia. Relativo à forma do edeago cujo ápice é recurvado.

\section{Alchisme ustulata (Fairmaire, 1846)}

Figs $62-66$

Triquetra ustulata Fairmaire, 1846: 281 (Loc. tipo: Colômbia, Bogotá).

Triquetra oppugnans Walker, 1858: 131 (Loc. tipo: Venezuela). -Funkhouser, 1927: 79. - Metcalf \& Wade, 1965: 563. - McKamey \& Deitz, 1996: 313.

Alchisme ustulata; Funkhouser, 1927: 79. - Metcalf \& Wade, 1965: 563. - Restrepo-Mejia, 1980: 144. - McKamey \& Deitz, 1996: 313.

Triquetra virgata Fairmaire, 1846: 282 (Loc. tipo: Colômbia, Bogotá). - Metcalf \& Wade, 1965: 563. - McKamey \& Deitz, 1996: 313 (= A. virescens) (error). Syn.n.

Medidas. Fêmea/macho. Comprimento do corpo 12,67/11,83; largura da cabeça 3,83/3,67; distância entre os processos ad-umerais 10,17/9,33.

Diagnose. Colorido geral escuro; pronoto elevado acima dos úmeros em forma de um processo; metopídio e processos ad-umerais pretos; tégminas escuras.

Descrição. Colorido geral escuro; metopídio com uma grande mancha vertical preta; carena mediana preta; processos ad-umerais pretos; tégminas escuras; abdome escuro.

Cabeça triangular, bem definida. Olhos elípticos. Ocelos ligeiramente mais aproximados entre si do que dos olhos, situados sobre a linha imaginária que passa pelo centro dos olhos. Pós-clípeo ligeiramente piloso, sem intumescências laterais. Lóbulos suprantenais não projetados para fora.

Pronoto elevado acima dos úmeros em um processo mais ou menos delgado e obtuso, levemente inclinado para frente. Processos ad-umerais bem desenvolvidos, delgados, acentuadamente voltados para os lados, ligeiramente para frente e para cima; margens inferiores alcançando os olhos. 


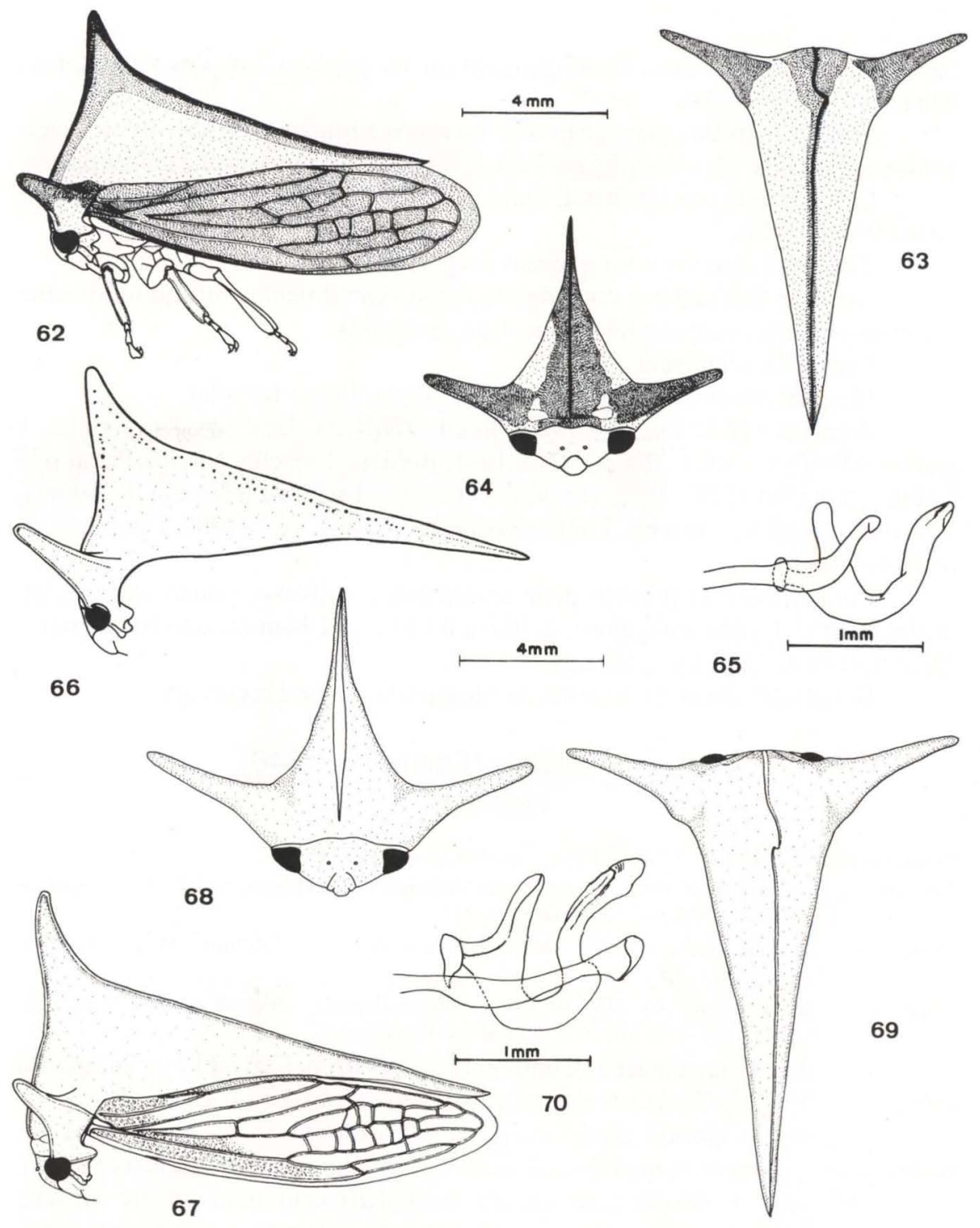

Figs 62-70. (62-66) Alchisme ustulata: (62-65) macho, (66) fêmea. (67-70) Alchisme virescens, macho. reduzidos.

Coxas II com espinho basal; tíbias III sem setas cuculadas; tarsos III Tagminas com veias transversais irregulares.

Abdome comprimido lateralmente; edeago ligeiramente declinado para trás, com espinhos subapicais diminutos e dispostos em semicírculo.

Fêmea. Maior que o macho; de coloração amarelada. 
Material examinado (só localidades). PERU:Acobamba; Cuzco/Machupichu (2.400m); Cuzco/Pilcopata; Chanchamayo; Junin/San Ramón/Mina Pichita $(1.200 \mathrm{~m})$; Huanuco/Tingo Maria. EQUADOR:Baños $(1.600 \mathrm{~m})$; La Palmera $(2.700 \mathrm{~m})$; Paramo de Anango; Rio Blanco. (AMNH; NCSU).

Comentários. Os machos variam na coloração podendo ser claros como as fêmeas. Triquetra virgata Fairmaire, descrita a partir de uma fềmea, é aqui sinonimizada.

\section{Alchisme virescens (Fairmaire, 1846)}

Figs 68-70

Triquetra virescens Fairmaire, 1846: 281 (Loc. tipo: Colômbia, Bogotá). - Funkhouser, 1927: 76 (= A grossa) (error).

Alchisme virescens; Kirkaldy, 1904: 279. - Metcalf \& Wade, 1965: 563. - Retrepo-Mejia, 1980: 146. McKamey \& Deitz, 1996: 313.

Alchisme spinosa Funkhouser, 1940: 278 (Loc. tipo:Peru). - Metcalf \& Wade, 1965: 562. - McKamey \& Deitz, 1996: 313. Syn.n.

Medidas. Fêmea/macho. Comprimento do corpo 13,67/11,83; largura da cabeça 4,00/3,67; distância entre os processos ad-umerais 11,33/9,02.

Diagnose. Pronoto elevado acima dos úmeros em um processo mais ou menos delgado, obtuso e com o ápice ligeiramente curvado para trás.

Descrição. Fêmea. Colorido geral amarelo-acastanhado; carena mediana avermelhada; tégminas amarelas.

Cabeça triangular, bem definida. Olhos elípticos. Ocelos equidistantes entre si e dos olhos, situados sobre a linha imaginária que passa pelo centro dos olhos. Pós-cleo piloso, sem intumescências laterais. Lóbulos suprantenais não projetados para fora.

Pronoto elevado acima dos úmeros em um processo mais ou menos delgado, obruso, levemente inclinado para frente e com o ápice ligeiramente voltado para trás. Processos ad-umerais bem desenvolvidos, delgados, acentuadamente voltados para os lados, levemente para frente e para cima; margens inferiores alcançando os olhos.

Coxas II com espinho basal; tíbias III sem setas cuculadas; tarsos III reduzidos.

Tégminas com veias transversais irregulares.

Abdome comprimido lateralmente.

Macho. Semelhante, apenas menor. Edeago defletido para trás.

Material examinado (só localidades). CosTA RICA: Cartago/ Cachi $(1.200 \mathrm{~m})$; Cartago/Embalse El Llano (1.500m); La Luiza de Turrialba; Cartago/Reserva Tupanti $(1.600 \mathrm{~m})$; San Jose; Cartago/ San Ramon de tres rios $(1.500 \mathrm{~m})$; Puntarenas/Reserv. Biol. Monteverde (1.520m). PANAMÁ: (sem localidade). PERU:Santo Domingo; Sinchona (4.600ft).

Comentários. A forma do processo dorsal varia um pouco, podendo ser reto e vertical confundindo com A. ustulata. A distinção se faz pela genitália. 


\section{Alchisme elevata Goding, 1930}

Figs 71-73

Alchisme elevata Goding, 1930: 10 (Loc. tipo: Bolívia, Beni). -Metcalf \& Wade, 1965: 557. - McKamey \& Deitz, 1996: 312.

Medidas. Fêmea. Comprimento do pronoto 11,17; largura da cabeça 3,67; distância entre os processos ad-umerais 8,83.

Diagnose. Pronoto elevado acima da cabeça, de contorno arredondado.

Descrição. Fêmea. Colorido geral amarelo.

Cabeça triangular, bem definida. Olhos elípticos. Ocelos equidistantes entre si e dos olhos, situados logo acima da linha imaginária que passa pelo centro dos olhos. Pós-clípeo ligeiramente piloso, sem intumescências laterais. Lóbulos suprantenais não projetados para fora.

Pronoto elevado acima da cabeça, com a parte mais elevada de contorno arredondado. Processos ad-umerais bem desenvolvidos, delgados, voltados para frente e para os lados; margens inferiores alcançando os olhos.

Coxas II com espinho basal; tíbias III sem setas cuculadas nas fileiras I e II; tarsos III reduzidos.

Abdome comprimido lateralmente.

Material examinado. Holótipo fêmea. BoLíviA:Beni, 10.II.1910, Matauch. $(\mathrm{AMNH})$. (Sem as tégminas e asa esquerda).

Comentários. A espécie aproxima-se de $A$. grossa, diferindo pelo pronoto mais elevado e fortemente arredondado, assim como pela carena mediana amarela.

\section{Alchisme grossa (Fairmaire, 1846)}

Figs 74-78

Triquetra grossa Fairmaire, 1846:280 (Loc. tipo: Colômbia).

Triquetra obtusa Fowler, 1894a: 417 (Loc. tipo: Colômbia). -McKamey \& Deitz, 1996: 312 (Design. Lectótipo).

Alchisne grossa; Funkhouser, 1927: 76. - Metcalf \& Wade, 1965: 558. - Restrepo-Mejia, 1980: 126. McKamey \& Deitz, 1996: 312.

Medidas. Fêmea/macho. Comprimento do corpo 14,00/11,50; largura da cabeça 4,33/3,83; distância entre os processos ad-umerais 11,17/8,75.

Diagnose. Pronoto elevado acima dos úmeros, com a parte mais elevada angulosa; carena mediana avermelhada, delimitada por pontuações escuras mais grosseiras.

Descrição. Fêmea. Colorido geral amarelo-acastanhado; carena mediana avermelhada delimitada por pontuações escuras.

Cabeça triangular, bem definida. Olhos elípticos. Ocelos ligeiramente mais aproximados entre si do que dos olhos, situados logo abaixo da linha imaginária que passa pelo centro dos olhos. Pós-clípeo ligeiramente piloso, sem intumescências laterais. Lóbulos suprantenais não projetados.

Pronoto elevado, tectiforme, em vista lateral triangular, com a parte mais elevada angulosa, situada acima dos úmeros, levemente declinada para frente. 
Metopídio reto. Processos ad-umerais bem desenvolvidos, delgados, voltados para frente e para cima, acentuadamente para os lados; margens inferiores alcançando os olhos.

Coxas II com espinho basal; tíbias III sem setas cuculadas nas fileiras I e II; tarsos III reduzidos.

Tégminas com veias transversais irregulares.

Abdome comprimido lateralmente.
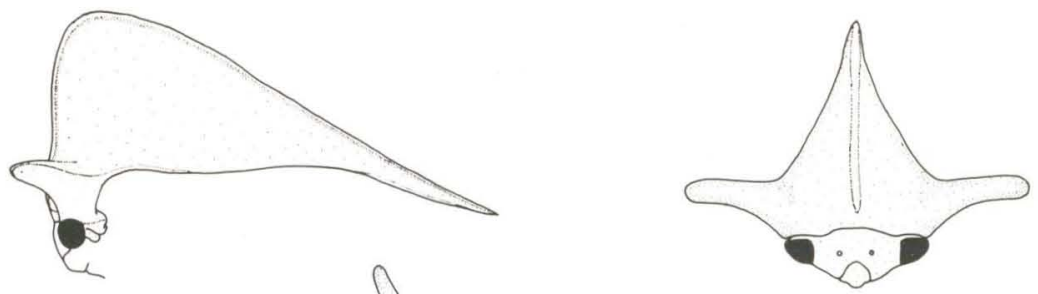

71

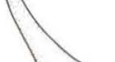

72

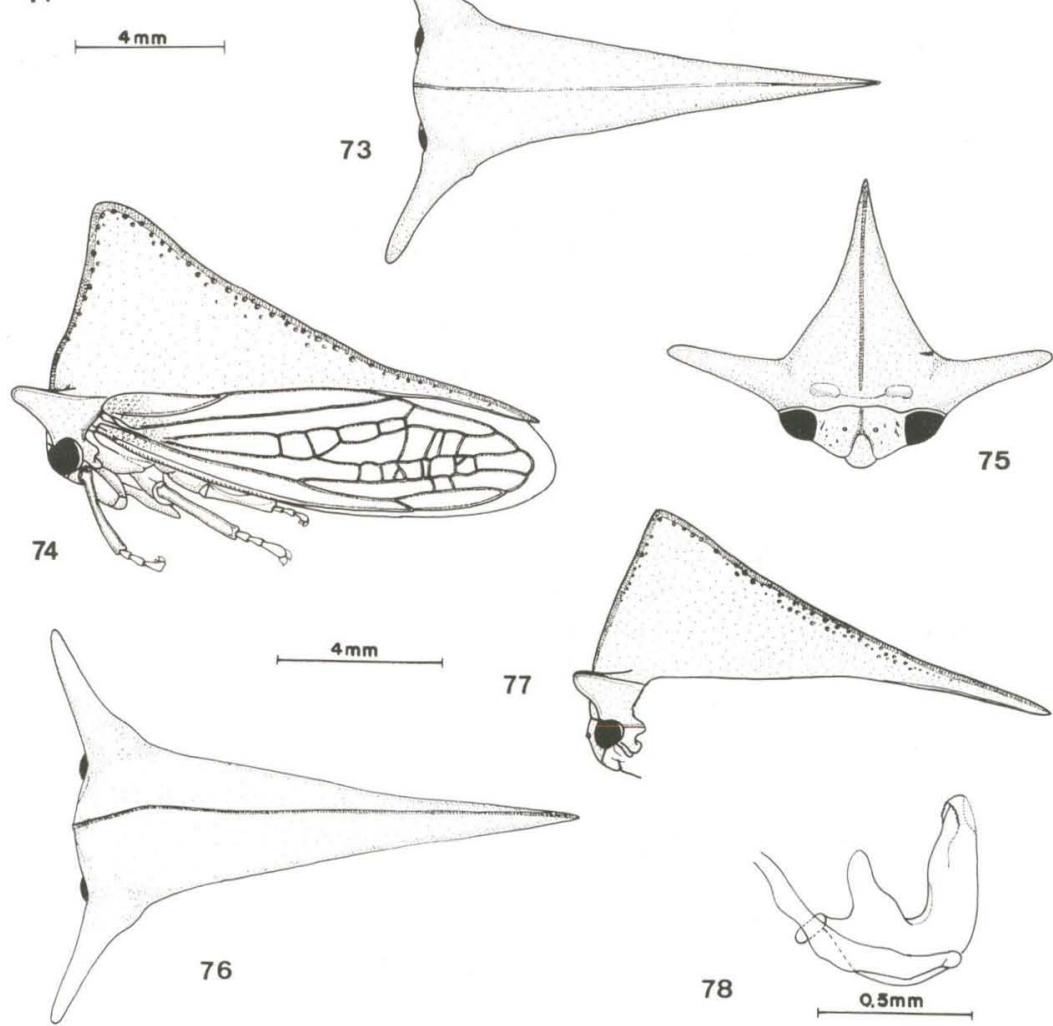

Figs 71-78. (71-73) Alchisme elevata, holótipo fêmea. (74-78) Alchisme grossa: (74-76) fêmea, (77-78) macho. 
Material examinado (só localidades). CoLÔMBIA: Bogotá; Bogotá/Solamm $(2.700 \mathrm{~m})$; Cachipay $(1.620 \mathrm{~m})$; carretera Mesitas del Colegio $(1.800 \mathrm{~m})$; el Chico (2.600-3.00m); Cundinamarca/ Guasca/ Gacheta (2.800m); Huila/P[arque] Nac[ional] Puracê $(2.500 \mathrm{~m})$; Tequendama $(2.400 \mathrm{~m})$. EQUAdoR: Baños $(2.200 \mathrm{~m})$; Cotopaxi (1.500m); Quito/Sto. Domingo (2.000m) (AMNH; DZUP; ZMUH)

Comentários. A espécie aproxima-se de $A$. salta sp.n., diferindo pelo pronoto mais elevado e anguloso.

\section{Alchisme salta sp.n.}

Figs $79-83$

Medidas. Fêmea/macho. Comprimento do corpo 10,00/9,17; largura da cabeça 3,33/3,08; distância entre os processos ad-umerais 6,08/6,25.

Diagnose. Pronoto elevado acima dos úmeros, com a parte mais elevada arrendondada; carena mediana avermelhada; metopídio com mancha marrom-avermelhada em forma de V.

Descrição. Holótipo fêmea. Colorido geral amarelo-acastanhado; cabeça com manchas escuras junto dos olhos; metopídio com mancha marrom-avermelhada em forma de $\mathrm{V}$ invertido, atingindo as impressões musculares; carena mediana avermelhada; tégminas acastanhadas.

Cabeça triangular, bem definida. Olhos elípticos. Ocelos equidistantes entre si e dos olhos, situados sobre a linha imaginária que passa pelo centro dos olhos. Pós-clípeo com pelos dispersos, sem elevações distintas. Lóbulos suprantenais não projetados.

Pronoto tectiforme, elevado acima dos úmeros, em vista lateral triangular, com a parte mais elevada arredondada. Processos ad-umerais bem desenvolvidos, voltados para frente e para os lados; margens inferiores alcançando os olhos.

Coxas II com espinho basal; tíbias III sem setas cuculadas nas fileiras I e II; tarsos III reduzidos.

Tégminas com inúmeras veias transversais irregulares.

Abdome ligeiramente comprimido dorso-ventralmente.

Macho. Menor, com elevação dorsal mais angulosa; face anterior dos processos ad-umerais, em geral, escurecida nos dois terços apicais; edeago em U, com espinhos diminutos subapicais dispostos em semicírculo.

Material examinado. Holótipo fêmea. ARgEnTINA: Salta/Campo Quijano (1.600m), 1-17.II.1984, Bordón (DZUP). Parátipos: ARGENTINA: Salta/San Lorenzo (1.350m), 19.IV.1972, Bordón, I fêmea; Salta P[arque] Nac[ional] Finca (800m), 21.II.1984, Bordón, 1 fêmea; Salta, 2 fêmeas; Tucuman, 14.VIII.1899, S. Venturi, 1 fêmea. BolíviA: Cochabamba, XII.1950, 5 fêmeas e 1 macho; Cochabamba/Santa Cruz, 1 macho; Cochabamba (2.600m), Diringshofen, 3 fêmeas e 1 macho (DZUP; $\mathrm{BMNH}$; MZSP).

Material não pertencente à série-tipo. ARGENTINA: Parque Aconquija; Tucuman; Salta/Campo Santo; Salta/Meta. BolíviA: Cochabamba (DZUP; MZSP; USNM). 
Comentários. Esta espécie é parecida com A. grossa, diferindo pelo tamanho menor, a elevação dorsal arredondada e pela presença da mancha no metopídio. Etimologia. Alusivo à localidade-tipo.

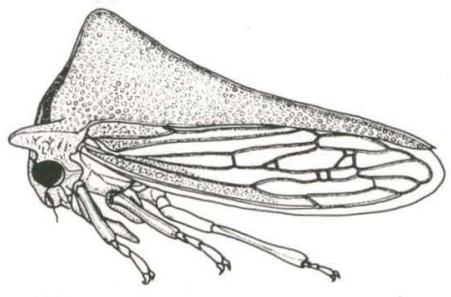

79

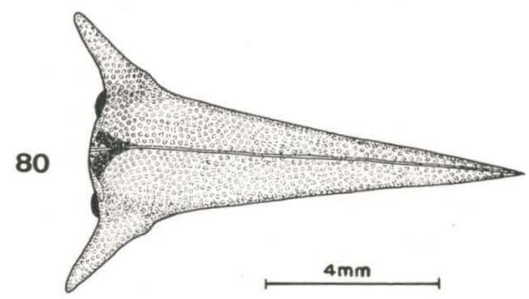

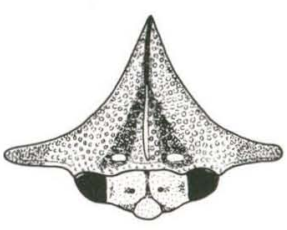

81

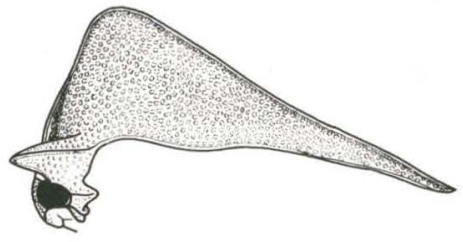

83

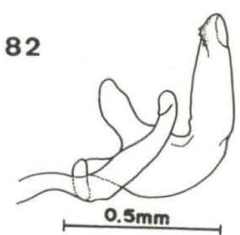

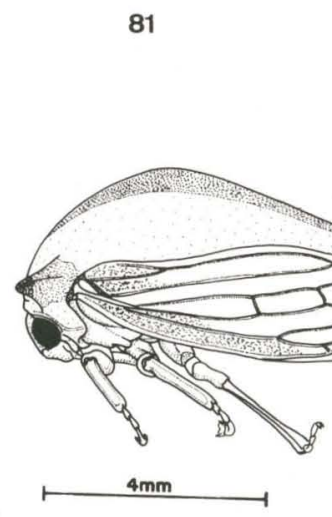

84
86

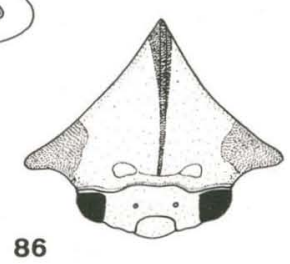

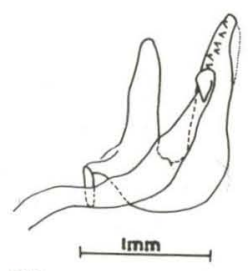

87

Figs 79-87. (79-83) Alchisme salta sp.n.: (79-82) macho, (83) fêmea. (84-87) Alchisme rubrocostata, macho.

\section{Alchisme rubrocostata (Spinola, 1852)}

Figs $84-86$

Hemiptycha rubro-costata Spinola, 1852:272 (Loc. tipo: Chile).

Smilia unicolor Signoret, 1863: 584 (Loc. tipo: Chile).

Smilia rubrocostata; Signoret, 1863: 584. - McKamey \& Deitz, 1996: 313.

Triquetra unicolor; Stål, 1867: 554. 
Triquetra rubrocostata; Stål, 1869: 266.

Alchisme rubrocostata; Funkhouser, 1927: 78. - Metcalf \& Wade, 1965: 561. - Restrepo-Mejia, 1980: 136. - McKamey \& Deitz, 1996: 313.

Alchisme neuquina Remes-Lenicov, 1978: 113 (Loc. tipo: Argentina). -McKamey \& Deitz, 1996: 312.

Syn.n.

Medidas. Fêmea/macho. Comprimento do corpo 7,25/7,50; largura da cabeça 2,36/2,36; distância entre os processos ad-umerais 3,50/3,25.

Diagnose. Pronoto convexo, pouco elevado; carena mediana vermelha; processos ad-umerais curtos e robustos, com a face anterior vermelha.

Descrição. Fêmea. Colorido geral amarelo-acastanhado; carena mediana avermelhada; processos ad-umerais com a face anterior vermelha.

Cabeça subtriangular. Olhos globulares. Ocelos mais aproximados dos olhos do que entre si, situados logo acima da linha imaginária que passa pelo centro dos ollhos. Pós-clípeo globoso, sem intumescências distintas. Lóbulos suprantenais projetados para frente.

Pronoto convexo, pouco elevado; processos adumerais curtos e robustos, dirigidos para frente e para os lados.

Coxas II com espinho basal; tíbias III sem setas cuculadas nas fileiras I e II; tarsos III reduzidos.

Tégminas com algumas veias transversais irregulares.

Abdome ligeiramente comprimido dorso-ventralmente.

Macho. Menor; edeago em U, com inúmeros espinhos subapicais bem definidos e dispersos na superfície interna.

Material examinado. Lectótipo macho, aqui designado: "Chili, D. Gay/ Hemiptycha rubrocostata (Triquetra) m. n. sp.". (MRSN). Paralectótipos, 2 fêmeas, aqui designados: "Chili, D. Gay/ Hemiptycha rubrocostata (Triquetra) m. n. sp." (MRSN).

Material não tipo (só localidades). CHILE: Arauco/Caramavida (1.000m); el Chissco; Los Vilos/Coquimbo (200m); Niebla/Valdivia (100m); Nublo/ Las Francas; Santiago; Talca/ 70 Km (1.000m); Volcán Osorno (400m) (Coleção Bordón; MZSP; NCSU).

Comentários. A espécie apresenta variações, sobretudo no tamanho e na intensidade da cor avermelhada da carena mediana e dos processos ad-umerais. Pode apresentar também, mancha marrom-escura no metopídio e na parte apical do processo posterior.

\section{Alchisme schuhi sp.n.}

Figs $88-92$

Medidas. Fêmea/macho. Comprimento do corpo 10,83/10,67; largura da cabeça 3,75/3,58; distância entre os processos ad-umerais 6,17/5,83.

Diagnose. Pronoto convexo, levemente elevado, de coloração amarela; processos ad-umerais curtos, voltados para frente; edeago com espinhos subapicais diminutos. 


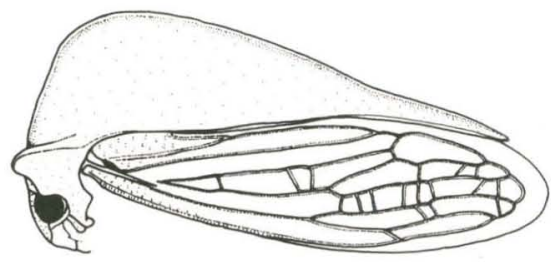

88
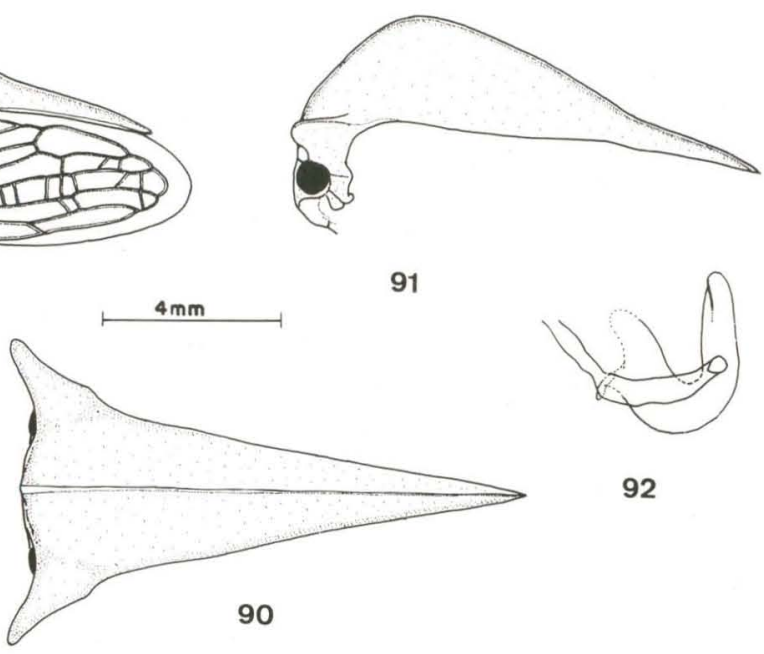

91

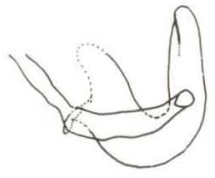

92

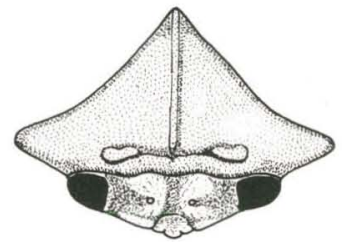

94

93
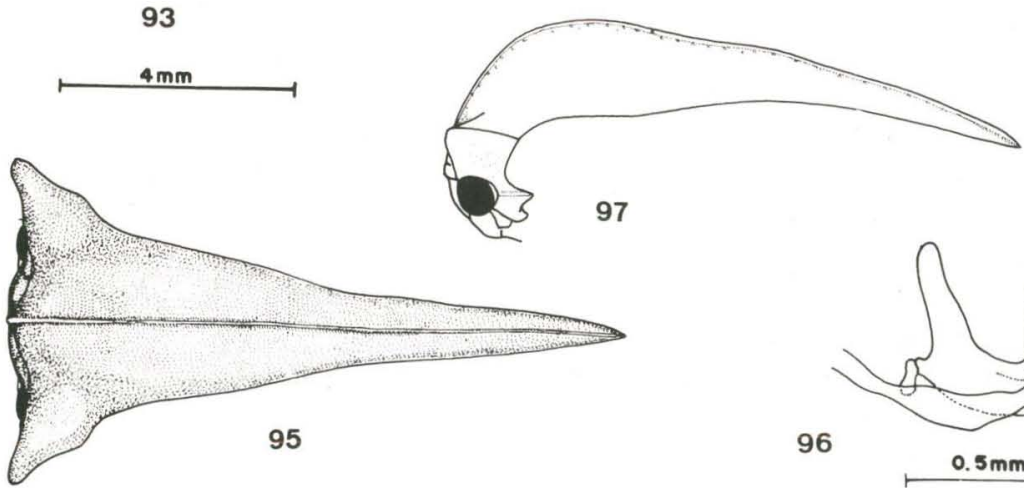

97

Figs 88-97. (88-92) Alchisme schuhi sp.n.: (88-90) holótipo fêmea, (91-92) macho. (93-97) Alchisme henryi sp.n.: (93-96) macho, (97) fêmea.

Descrição. Holótipo fêmea. Colorido geral amarelo.

Cabeça triangular, bem definida. Olhos elípticos. Ocelos ligeiramente mais aproximados entre si do que dos olhos, situados logo abaixo da linha imaginária que passa pelo centro dos olhos. Pós-clípeo sem intumescências laterais. Lóbulos suprantenais não projetados. 
Pronoto convexo, levemente elevado pouco atrás dos úmeros. Processos ad-umerais curtos, voltados para frente e para os lados; margens inferiores alcançando os olhos.

Coxas II com espinho basal; tíbias III sem setas cuculadas; tarsos III reduzidos.

Tégminas com veias transversais irregulares.

Abdome comprimido lateralmente.

Macho. Ligeiramente menor, com a parte mais elevada do pronoto situada muito atrás dos úmeros. Edeago em $\mathrm{U}$, com espinhos subapicais diminutos, quase imperceptíveis.

Material examinado. Holótipo fêmea. PERU: Lima/Surco (1.900-2.100m), 17.VIII.1965, B. \& B. W. Wygodzinsky. (AMNH). Parátipos: 2 fềmeas e 1 macho com os mesmos dados do holótipo (AMNH); 1 macho e 1 fêmea de Lima, 30.VI.1928, Verrugas (USNM).

Comentários. A espécie aproxima-se de $A$. rubrocostata pela forma do pronoto; difere entretanto, pelo tamanho maior, carena mediana concolorida e principalmente pela estrutura da genitália do macho.

Etimologia. Espécie dedicada ao Dr. Randall T. Schuh, do USNM.

\section{Alchisme henryi sp.n.}

Figs $93-97$

Medidas. Fêmea/macho. Comprimento do corpo 10,32/8,83; largura da cabeça 3,50/3,00; distância entre os processos ad-umerais 6,42/5,08.

Diagnose. Pronoto convexo, pouco elevado; edeago voltado para cima, com espinhos diminutos subapicais em semicírculo.

Descrição. Holótipo macho. Colorido geral castanho-escuro; cabeça com manchas escuras, uma sobre a linha mediana e outras junto e lateralmente aos ocelos; pronoto com pontuação castanho-escura sobretudo nas faces dos processos ad-umerais; tégminas escurecidas.

Cabeça triangular, bem definida. Olhos elípticos. Ocelos ligeiramente mais aproximados entre si do que dos olhos, situados logo abaixo da linha imaginária que passa pelo centro dos olhos. Pós-clípeo com pelos dispersos. Lóbulos suprantenais não projetados.

Pronoto convexo, pouco elevado. Processos ad-umerais desenvolvidos, voltados para frente e para os lados; margens inferiores alcançando os olhos.

Coxas II com espinho basal; tíbias III sem setas cuculadas nas fileiras I e II; tarsos III reduzidos.

Tégminas com veias transversais irregulares.

Abdome comprimido dorso-ventralmente. Edeago voltado para cima, com espinhos diminutos subapicais, dispostos em semicírculo; superfície interna subapical intumescida.

Fêmea. Maior, de coloração amarelada. Pronoto com a elevação dorsal pouco mais acentuada. 
Material examinado. Holótipo macho. VenEzUELA: Mérida/ Páramo Mucubai/ Lag. Negra Area, 28-31.X.1989, A. L. Norrbom. (USNM). Parátipos: 8 fêmeas e 6 machos, com os mesmos dados do holótipo (USNM); Mérida (11 Km. SW de Santo Domingo), 16.III.1982, G.F. \&.F. Hevel, 3 machos (USNM); Tachira/P[ara]mo la Negra (3.100m), C. Bordón, 2 machos e 2 fêmeas (Coleção Bordón); Mérida/P[ara]mo La Culata (3.100m), 19-31.V.1977, C. Bordón, 1 macho e 1 fềmea (Coleção Bordón); Mérida/ Portachuelo/ Tovar (3.300m), 15.III.1978, C. Bordón, 1 fềmea e 1 macho (Coleção Bordón).

Comentários. A espécie aproxima-se de $A$. deflexa sp.n., diferindo apenas no aspecto da genitália; o edeago é voltado para cima e não fortemente defletido para trás como em $A$. deflexa.

Etimologia. Espécie dedicada ao Dr. Thomas Henry, do USNM.

\section{Alchisme testacea (Fairmaire, 1846), sp. rev.}

Figs $98-102$

Triquetra testacea Fairmaire, 1846: 281 (Loc. tipo: Colômbia, Bogotá). - Funkhouser, 1927: 79. -

Metcalf \& Wade, 1965: 562. -McKamey \& Deitz, 1996: 313 (= Alchisme truncaticornis) (error).

Medidas. Fêmea/macho. Comprimento do corpo 10,83/10,67; largura da cabeça 3,17/3,17; distância entre os processos ad-umerais 7,08/6,58.

Diagnose. Pronoto elevado acima dos úmeros em um processo obtuso, levemente inclinado para frente.

Descrição. Colorido geral amarelo-acastanhado; tégminas acastanhadas.

Cabeça sub-triangular, com duas depressões próximas da margem lateral externa dos ocelos. Olhos globulares. Ocelos equidistantes entre si e dos olhos, situados sobre a linha imaginária que passa pelo centro dos olhos. Pós-clípeo piloso, com duas discretas intumescências laterais, adjacentes às margens internas dos lóbulos suprantenais; estes projetados para fora.

Pronoto grosseiramente pontuado, elevado acima dos úmeros em um processo obtuso, levemente inclinado para frente. Processos ad-umerais bem desenvolvidos, robustos, voltados para frente e para os lados; margens inferiores alcançando os olhos.

Coxas II com espinho basal; tíbias III com setas cuculadas nas fileiras I e II; tarsos III reduzidos.

Tégminas com venação normal.

Abdome ligeiramente comprimido dorso-ventralmente.

Macho. Menor, com processo dorsal mais ou menos vertical.

Material examinado (só localidades). BRASIL: Minas Gerais/ Serra Caraça $(1.800 \mathrm{~m})$; Rio de Janeiro/Nova Friburgo/Mury; Rio de Janeiro/Itatiaia; São Paulo/Campos do Jordão; Pará/Belém. (MZSP).

Comentários. STÅL (1869b) colocou esta espécie em sinonímia de Alchisme truncaticornis (Germar, 1835) e assim permaneceu (FUNKHOUSER 1927; METCALF \& WADE 1965). Juntamente com outros exemplares da coleção Spinola que foram obtidos por empréstimo, encontrou-se um de Triquetra testacea Fairmaire, portando 
uma etiqueta "Lectótipo". Como não há registro na literatura da designação de lectótipo para esta espécie, é possível que esta etiqueta tenha sido anexada ao exemplar apenas para indicar, na coleção, os exemplares-tipos. Todavia, como o exemplar fora usado por Fairmaire para descrever a espécie, foi comparado com a descrição de $H$. truncaticornis concluindo-se que se tratam de espécies distintas.
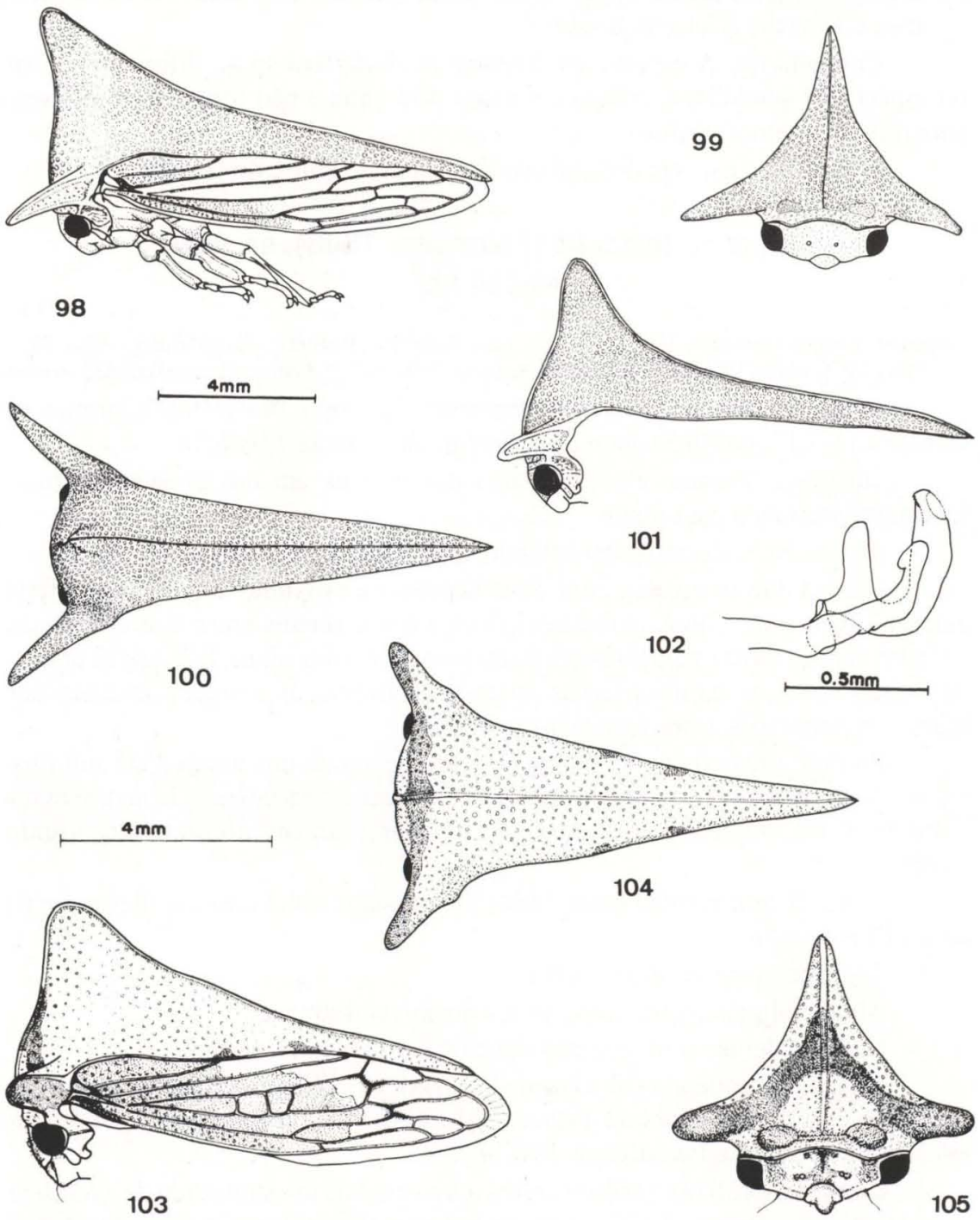

Figs 98-105. Alchisme testacea (Fairmaire): 98-100, fêmea; 101,102, macho. Alchisme colombiana sp.n.: 103-105, fêmea (holótipo). 


\section{Alchisme colombiana sp.n.}

Figs 103-105

Medidas. Fêmea. Comprimento do corpo 8,92; largura da cabeça 3,08; distância entre os processos ad-umerais 5,50.

Diagnose. Pronoto elevado acima dos úmeros em um processo largamente obtuso; metopídio com mancha avermelhada em forma de V invertido; tégminas coriáceas nos dois terços basais.

Descrição. Holótipo fêmea. Colorido geral amarelo; cabeça com manchas escuras no meio, junto dos ocelos e junto dos olhos; metopídio com mancha marrom-avermelhada, em forma de $\mathrm{V}$ invertido, com os ramos estendendo-se até a ponta dos processos ad-umerais; estes com as faces escuras; processo posterior com duas pequenas manchas avermelhadas junto às margens laterais; tégminas amareladas.

Pronoto tectiforme, elevado acima dos úmeros em um processo largamente arredondado no ápice. Processos ad-umerais bem desenvolvidos, robustos, dirigidos para frente e para os lados; margens inferiores alcançando os olhos.

Coxas II com espinho basal; tíbias III com setas cuculadas nas fileiras I e II; tarsos III reduzidos.

Tégminas coriáceas nos dois terços basais; venação normal ou com algumas veias transversais irregulares.

Abdome ligeiramente comprimido dorso-ventralmente.

Macho. Desconhecido.

Material examinado. Holótipo fêmea. ColôMBIA: Cundinamarca/ Tabio, 22.V.1946, Chapin (UCMS).

Comentários. A espécie aproxima-se de A. frontomaculata diferindo na mancha do metopídio que é menor, nas tégminas coriáceas na base e os processos ad-umerais voltados para os lados, não para baixo.

Etimologia. O nome da espécie alusivo ao país onde foi coletado o exemplar-tipo.

\section{Alchisme frontomaculata sp.n.}

Figs 106-110

Medidas. Fêmea/macho. Comprimento do corpo 9,00/8,17; largura da cabeça 2,92/2,58; distância entre os processos ad-umerais 4,42/4,00.

Diagnose. Pronoto elevado acima dos úmeros em um pequeno processo de ápice obtuso; metopídio com mancha castanho-escura em forma de $\mathrm{V}$ cujos ramos alcançam as impressões musculares.

Descrição. Holótipo fêmea. Colorido geral castanho-amarelado; cabeça com manchas acastanhadas irregulares; metopídio com mancha castanho-escura em forma de $\mathrm{V}$ invertido, com os ramos alcançando as impressões musculares; processo posterior com duas pequenas manchas castanho-escuras junto às margens laterais; tégminas acastanhadas. 

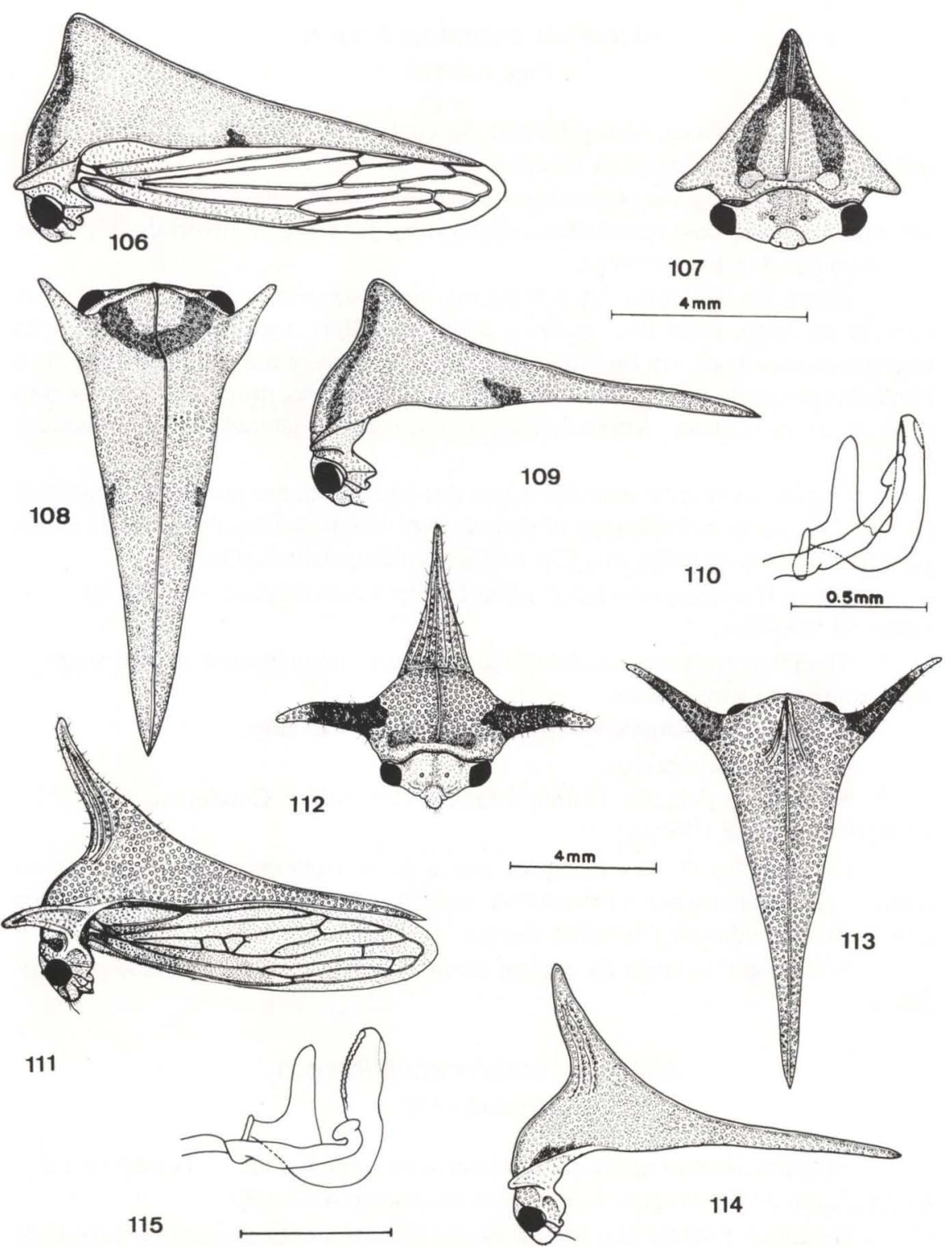

Figs 106-115. (106-110) Alchisme frontomaculata sp.n.: (106-108) fêmea, (109-110) macho. (111-115) Alchisme apicalis: (111-113) fêmea, (114-115) macho.

Cabeça subtriangular. Olhos globulares. Ocelos equidistantes entre si e dos olhos, situados sobre a linha imaginária que passa pelo centro dos olhos. Pós-clípeo piloso, com duas discretas intumescências laterais, adjacentes às margens internas dos lóbulos suprantenais. Lóbulos suprantenais projetados para fora. 
Pronoto elevado acima dos úmeros em um pequeno processo de ápice obtuso. Processos ad-umerais desenvolvidos, voltados para frente, para os lados e para baixo; margens inferiores alcançando os olhos.

Coxas II com espinho basal; tíbias III com setas cuculadas nas fileiras I e II; tarsos III reduzidos.

Tégminas com venação normal.

Abdome ligeiramente comprimido dorso-ventralmente.

Macho. Menor. Em alguns exemplares examinados, com a mancha do metopídio triangular, ocupando quase toda a área.

Material examinado. Holótipo fềmea. BRASIL: São Paulo/Campos do Jordão (1.600m), 23.XII.1944, F. Lane (MZSP). Parátipos: BRASIL:Rio Grande do Sul/Porto Alegre, 1926, 1 fềmea; Santa Catarina/Lages, 1 fêmea; Santa Catarina/São Bento do Sul/ Rio Vermelho, Diringshofen, 1 macho; São Paulo/Campos do Jordão, 23.XII.1944, F. Lane, 8 fêmeas e 3 machos; do mesmo local, XII.1947, F. Lane, 7 fêmeas (BMNH; MZSP).

Comentários. A espécie aproxima-se de A. colombiana mas difere pela forma da mancha do metopídio e pelas tégminas que não são coriáceas na base.

Etimologia. O nome da espécie é alusivo à presença da mancha no metopídio.

\section{Alchisme apicalis (Walker, 1851)}

Figs $111-115,147$

Umbonia apicalis Walker, 1851: 518 (Loc. tipo: Colômbia). -Broomfield, 1971: 332.

Triquetra apicalis; Fowler, 1894b: 33.

Alchisme apicalis; Funkhouser, 1927: 76. - Metcalf \& Wade, 1965: 556. - Restrepo-Mejia, 1980: 118. - McKamey \& Deitz, 1996: 312.

Alchisme costaricensis Goding, 1929a: 171 (Loc. tipo: Costa Rica). - Metcalf \& Wade, 1965: 557. McKamey \& Deitz, 1996: 312. Syn.n.

Medidas. Fêmea/macho. Comprimento do corpo 10,33/10,33; largura da cabeça 3,08/3,08; distância entre os processos ad-umerais 8,33/6,50.

Diagnose. Processo dorsal bem desenvolvido, mais ou menos delgado e sinuoso, voltado para frente e para cima, carenado; processos ad-umerais longos, delgados, dirigidos para frente e para os lados, levemente curvados para baixo.

Descrição. Fêmea. Colorido geral castanho-escuro; processos ad-umerais com a face anterior enegrecida, exceto o ápice; tégminas acastanhadas.

Cabeça subtriangular. Olhos globulares. Ocelos mais aproximados entre si do que dos olhos, situados sobre a linha imaginária que passa pelo centro dos olhos. Pós-clípeo piloso, com duas intumescências laterais, adjacentes à margem interna dos lóbulos suprantenais.

Pronoto grosseiramente pontuado. Processo dorsal bem desenvolvido, delgado, carenado, voltado para frente e sinuosamente para cima, localizado atrás dos úmeros. Processos ad-umerais bem desenvolvidos, delgados, voltados para frente e para os lados, levemente curvados para baixo no terço apical; margens inferiores alcançando os olhos. 
Coxas II com espinho basal; tíbias III com setas cuculadas nas fileiras I e II; tarsos III reduzidos.

Tégminas com venação normal, podendo aparecer uma ou outra vênula transversal.

Abdome ligeiramente comprimido dorso-ventralmente.

Macho. Menor, com os processos ad-umerais curtos e escuros em toda superfície da face anterior; edeago em $\mathrm{U}$, com espinhos diminutos enfileirados ao longo da margem lateral interna, contornando o ápice.

Material examinado (só localidades). CoLÔMBIA: Mordiño/B. Manga; Fusagasuga (1.900m). CosTA RICA: Suiza/Turrialba. PANAMÁ: Chiriqui/Las Lagunas (1.400m) (USNM; ZMUH).

Holótipo macho de Alchisme costaricensis Goding. (NCSU).

Holótipo fêmea de Umbonia apicalis Walker (só fotografia). (BMNH).

Comentários. Os processos ad-umerais nas fêmeas podem variar: nem sempre são curvados para baixo; a mancha escura anterior pode ser maior, ocupando toda área anterior. Alchisme costaricensis Goding foi baseada em um exemplar macho.

\section{Alchisme obscura (Walker, 1851)}

Figs $116-120,148$

Umbonia obscura Walker, 1851: 517 (Loc. tipo: Brasil).

Triquetra obscura; Fowler, 1894b: 34.

Alchisme obscura; Funkhouser, 1927: 78. - Metcalf \& Wade, 1965: 562 (= A. turrita) (error). McKamey \& Deitz, 1996: 313.

Medidas. Fêmea/macho. Comprimento do corpo 10,17/8,50; largura da cabeça 3,08/2,67; distância entre os processos ad-umerais 6,92/5,58.

Diagnose. Processo dorsal bem desenvovido, mais ou menos delgado, carenado, voltado para frente e para cima, situado acima dos úmeros. nhadas.

Descrição. Fêmea. Colorido geral amarelo-acastanhado; tégminas acasta-

Cabeça triangular, com duas depressões próximas da margem lateral externa dos ocelos. Olhos globulares. Ocelos equidistantes entre si e dos olhos, situados sobre a linha imaginária que passa pelo centro dos olhos. Pós-clípeo piloso, com duas discretas intumescências laterais, adjacentes às margens internas dos lóbulos suprantenais.

Pronoto grosseiramente pontuado. Processo dorsal bem desenvolvido, mais ou menos delgado, quase reto, carenado, situado acima dos úmeros. voltados para frente e para os lados, levemente curvados para baixo. Processos ad-umerais bem desenvolvidos, robustos, voltados para frente e para os lados, levemente curvados para baixo; margens inferiores alcançando os olhos.

Coxas II com espinho basal; tíbias III com setas cuculadas nas fileiras I e II; tarsos III reduzidos.

Tégminas com venação normal.

Abdome ligeiramente comprimido dorso-ventralmente. 


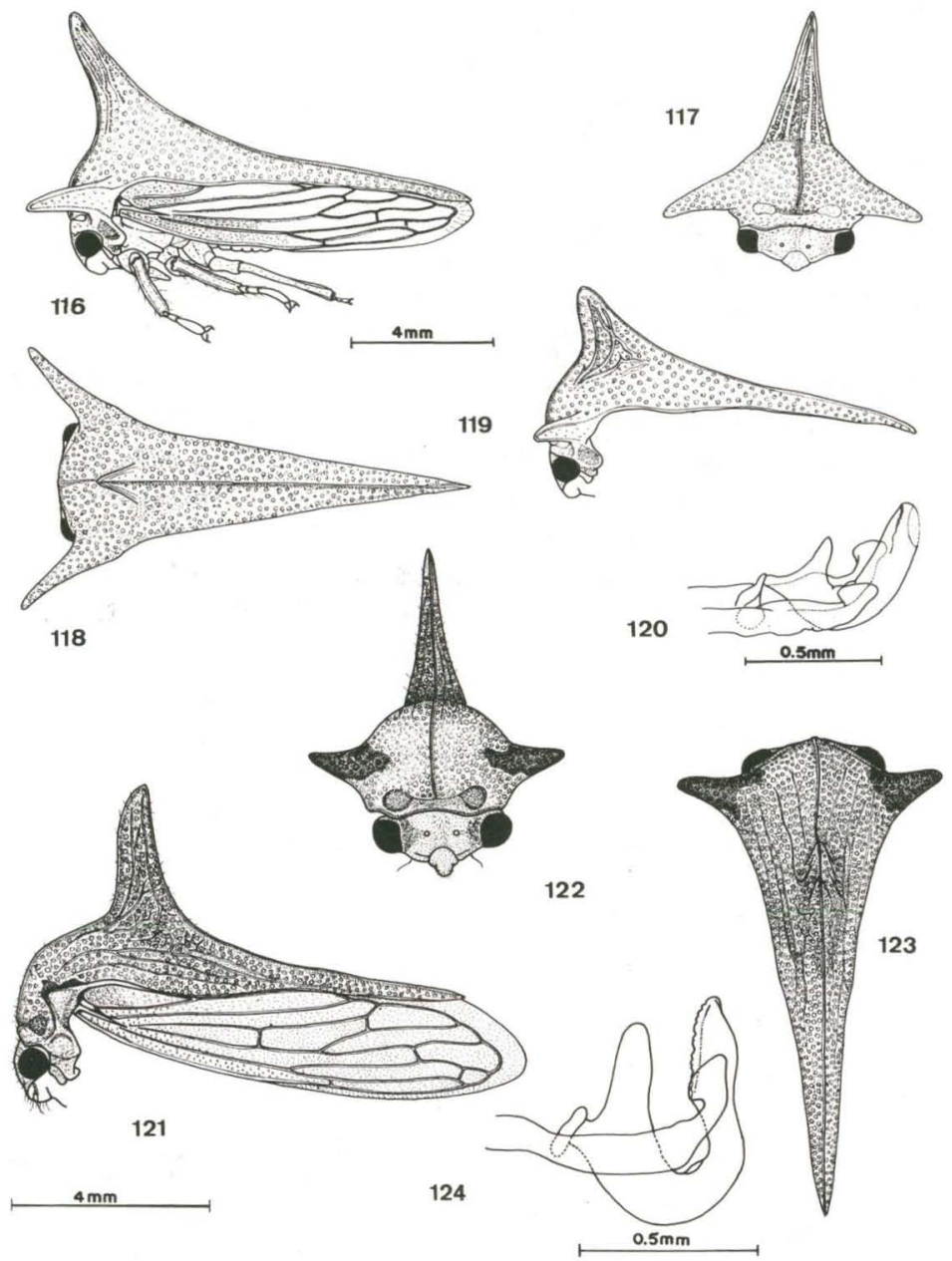

Figs 116-124. (116-120) Alchisme obscura: (116-118) fêmea, (119-120) macho. (121-124) Alchisme veruta, macho.

Macho. Menor, com processo dorsal e processos ad-umerais curtos; edeago em U, com espinhos diminutos enfileirados lateralmente, contornando o ápice.

Material examinado (só localidades). BRASIL: Minas Gerais/ Serra Caraça $(1.880 \mathrm{~m})$; Rio de Janeiro/Nova Friburgo; Rio de Janeiro/ Itatiaia (1.100m); São Paulo/Cantareira (MZSP).

Paralectótipo fêmea (BMNH).

Comentários. MetCALF \& WADE (1965) colocaram esta espécie em $A$. turrita (Germar), todavia trata-se de uma espécie distinta tanto que McKamey \& Deitz (1996) desfizeram a sinonímia; $A$. turrita é mais robusta, com manchas no metopídio e nas margens laterais do pronoto; $A$. obscura não apresenta tais manchas. É muito parecida também com A. apicalis. 


\section{Alchisme veruta (Fowler, 1894)}

Figs 121-124

Triquetra veruta Fowler, 1894b: 33 (Loc.-tipo: Panamá).

Alchisme veruta; Kirkaldy, 1904: 279; Funkhouser, 1927: 79; Metcalf \& Wade, 1965:563 (= A. turrita)

(error); McKamey \& Deitz, 1996: 313.

Medidas. Macho. Comprimento do corpo 9,83; largura da cabeça 2,75; distância entre os processos ad-umerais 5,00.

Diagnose. Pronoto carenado; processo dorsal aproximadamente vertical, carenado, levemente recurvado no ápice, situado atrás dos úmeros.

Descrição. Macho. Colorido geral acastanhado; cabeça com manchas escuras junto dos olhos; metopídio com impressões musculares escurecidas; processos ad-umerais com a face anterior escurecida; tégminas acastanhadas.

Cabeça subtriangular. Olhos globulares. Ocelos equidistantes entre si e dos olhos, situados sobre a linha imaginária que passa pelo centro dos olhos. Pós-clípeo piloso, carenado medianamente, com duas discretas intumescências laterais, adjacentes às margens internas dos lóbulos suprantenais.

Pronoto grosseiramente pontuado, com carenas laterais longitudinais. Processo dorsal bem desenvolvido, aproximadamente na vertical, com o ápice ligeiramente curvado para trás, carenado, situado atrás dos úmeros. Processos ad-umerais bem desenvolvidos, voltados para os lados; margens inferiores não alcançando os olhos.

Coxas II com espinho basal; tíbias III com setas cuculadas nas fileiras I e II; tarsos III reduzidos.

Tégminas com venação normal.

Abdome ligeiramente comprimido dorso ventralmente. Placa lateral do pigóforo distinta; Edeago em $\mathrm{U}$, com espinhos diminutos enfileirados nas margens laterais, contornando o ápice.

Material examinado (só localidades). Costa RicA: San José/ Zurqui de Moravia (1.600m). (MUCR).

Comentários. A. veruta foi colocada como sinônimo de A. turrita por GodING (1929c) e mantida assim por METCALF \& WADE (1965). MCKAMEY \& DEITZ (1996) revalidaram a espécie. $A$. veruta não é uma espécie muito comum, visto que apenas um exemplar foi encontrado dentro de todo material proveniente do Museu de Insetos da Universidade de Costa Rica. Aproxima-se de A. antigua pela presença das carenas no pronoto.

\section{Alchisme cultellata sp.n.}

Figs 125-132

Medidas. Fêmea/macho. Comprimento total 11,00/9,33; largura da cabeça 3,33/2,75; distância entre os processos ad-umerais 6,83/4,42.

Diagnose. Processo dorsal bem desenvolvido, carenado, situado acima dos úmeros, dirigido para frente, ápice truncado. Processos ad-umerais longos, mais ou menos espatulados. 

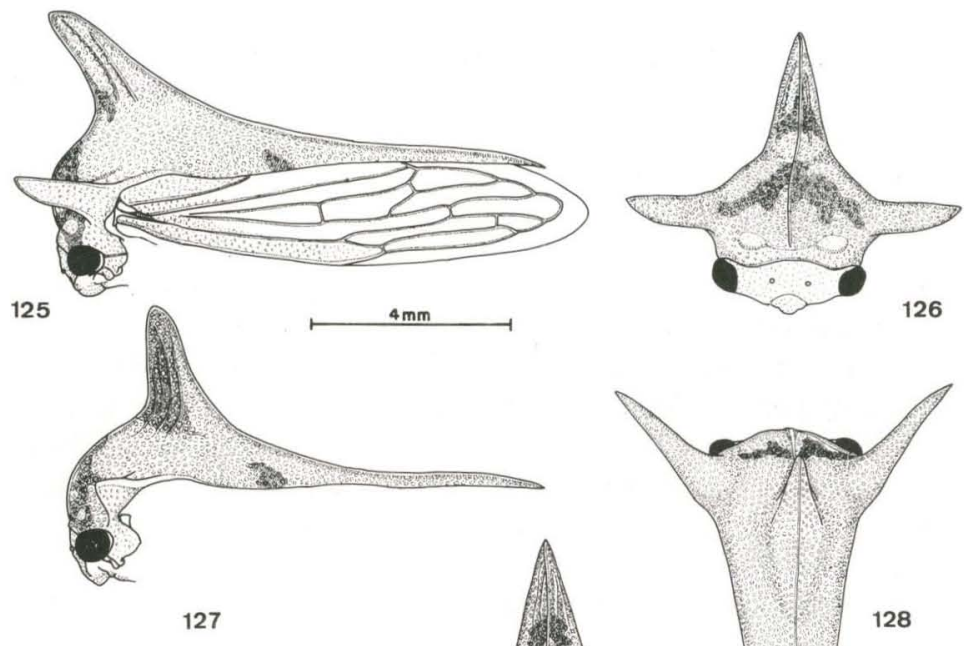

127
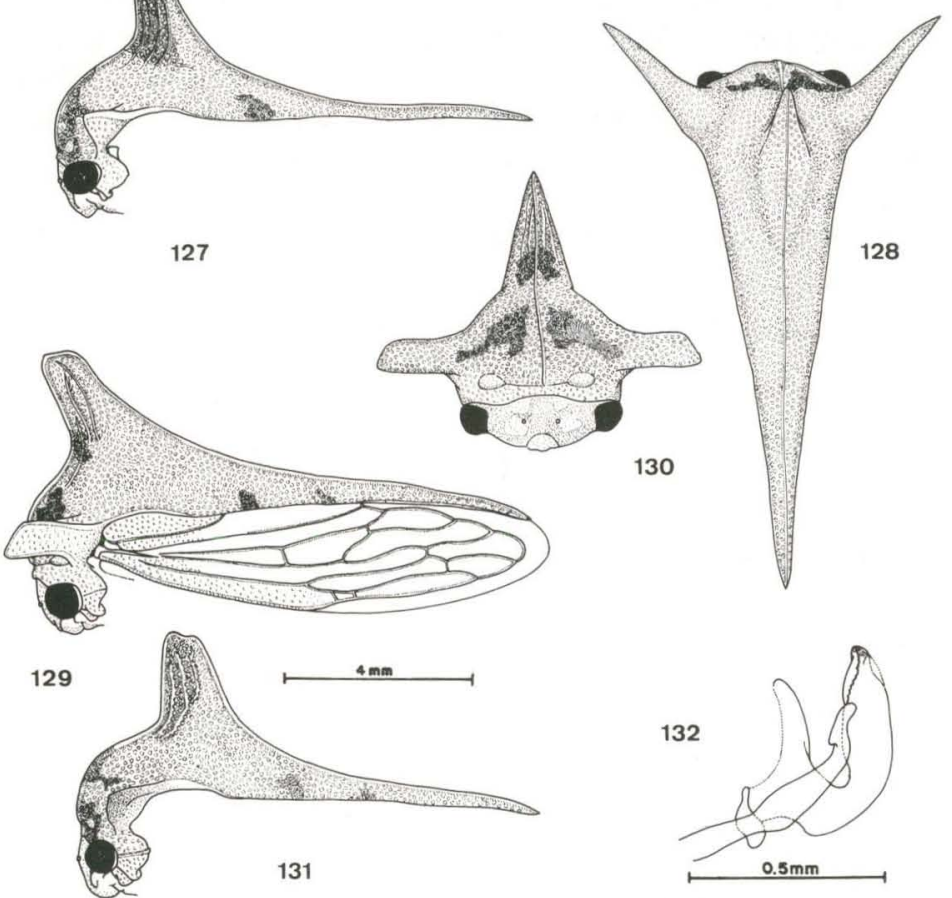

Figs 125-132. Alchisme cultellata sp.n.. (125-126) macho; (127) macho (variação); (128-130) fêmea; (131) macho (variação); (132) genitália.

Descrição. Holótipo fêmea. Colorido geral castanho; cabeça com manchas escuras; pronoto com pequena mancha castanho-avermelhada junto à margem lateral; metopídio e parte anterior basal do processo dorsal manchados de castanhoavemelhado; tégminas acastanhadas.

Cabeça subtriangular. Olhos globulares. Ocelos equidistantes entre si e dos olhos, situados sobre a linha imaginária que passa pelo centro dos olhos. Pós-clípeo piloso, deprimido próximo à sutura epistomal, com duas intumescências laterais adjacentes às margens internas dos lóbulos suprantenais.

Pronoto grosseiramente pontuado, piloso. Processo dorsal bem desenvolvido, situado acima dos úmeros, voltado para frente, carenado, com ápice truncado. 
Processos ad-umerais bem desenvolvidos, voltados para frente e para os lados, mais ou menos espatulados; margens inferiores não alcançando os olhos.

Coxas II com espinho basal; tíbias III com setas cuculadas mas fileiras I e II; tarsos III reduzidos.

Tégminas com venação normal.

Abdome ligeiramente comprimido dorso-ventralmente.

Macho. Processo dorsal, em geral, mais curto e mais largo, igualmente manchado anteriormente, de castanho-avermelhado.

Material examinado. Holótipo fêmea. VENEzUELA: Merida/ el Paramito/Jaji (2.500m), 4.III.1978, Bordón. (DZUP). Parátipos: ColÔMBIA: Huila/Par[que] Nac[ional] Puracê (2.300m), 1.VI.1972, Bordón, 3 fêmeas. (Coleção Bordón).

Comentários. Foram observadas variações acentuadas no processo dorsal e nos processos ad-umerais, tanto dos machos como das fềmeas; os ápices podem ser agudos ou truncados.

Etimologia. Relativo à forma do processo dorsal, semelhante a um cutelo.

\section{Alchisme turrita (Germar, 1835)}

Figs 133-137

Hoplophora turrita Germar, 1835: 243 (Loc. tipo: Brasil).

Umbonia turrita; Fairmaire, 1846: 276.

Triquetra turrita; Fowler, 1894b: 34.

Triquetra submaculata Buckton, 1901: 92 (Loc. tipo: Equador). -Funkhouser, 1927: 78 (= A. obscura) (error). - Metcalf \& Wade, 1965: 557. - McKamey \& Deitz, 1996: 312 (= A. fastidiosa) (error). Syn.n.

Triquetra insipida Buckton, 1901: 94 (Loc. tipo: desconhecida). -Funkhouser, 1927: 79. - Metcalf \& Wade, 1965: 562. - McKamey \& Deitz, 1996: 313.

Alchisme turrita; Kirkaldy, 1904: 279. - Funkhouser, 1927: 779. -Metcalf \& Wade, 1965: 562. Restrepo-Mejia, 1980: 142. - McKamey \& Deitz, 1996: 313.

Medidas. Fêmea/macho. Comprimento do corpo 11,67/10,83; largura da cabeça 3,38/3,25; distância entre os processos ad-umerais 7,33/6,83.

Diagnose. Processo dorsal bem desenvolvido, carenado, voltado para frente; metopídio com mancha castanho-escura.

Descrição. Fêmea. Colorido geral castanho; cabeça com manchas escuras; pronoto com metopídio e junto às margens laterais do processo posterior, castanhoescuros; tégminas acastanhadas.

Cabeça subtriangular. Olhos globulares. Ocelos ligeiramente mais aproximados entre si do que dos olhos, situados logo acima da linha imaginária que passa pelo centro dos olhos. Pós-clípeo piloso, com duas discretas intumescências laterais adjacentes às margens internas dos lóbulos suprantenais.

Pronoto grosseiramente pontuado. Processo dorsal bem desenvolvido, carenado, voltado para frente, situado acima dos úmeros. Processos ad-umerais bem desenvolvidos, robustos, voltados para frente, para os lados e para baixo; margens inferiores alcançando os olhos.

Coxas II com espinho basal; tíbias III com setas cuculadas nas fileiras I e II; tarsos III reduzidos. 
Tégminas com venação normal.

Abdome ligeiramente comprimido dorso-ventralmente.

Macho. Menor, com processo dorsal mais curto e largo; edeago em U, com espinhos diminutos subapicais; parâmeros com ápice intumescido.

Material examinado (só localidades). BRAsIL: Pará/Belém; Rio de Janeiro/Corcovado; São Paulo/Ubatuba/Moranduba. (DZUP; MZSP).

Comentários. O colorido geral varia do amarelo ao castanho-escuro; a mancha do metopídio pode se apresentar mais reduzida.

A espécie aproxima-se de A. goiana, diferindo nos seguintes aspectos: processos ad-umerais longos, estendendo-se à frente da cabeça; processo dorsal mais curto; ápice dos parâmeros dilatados.

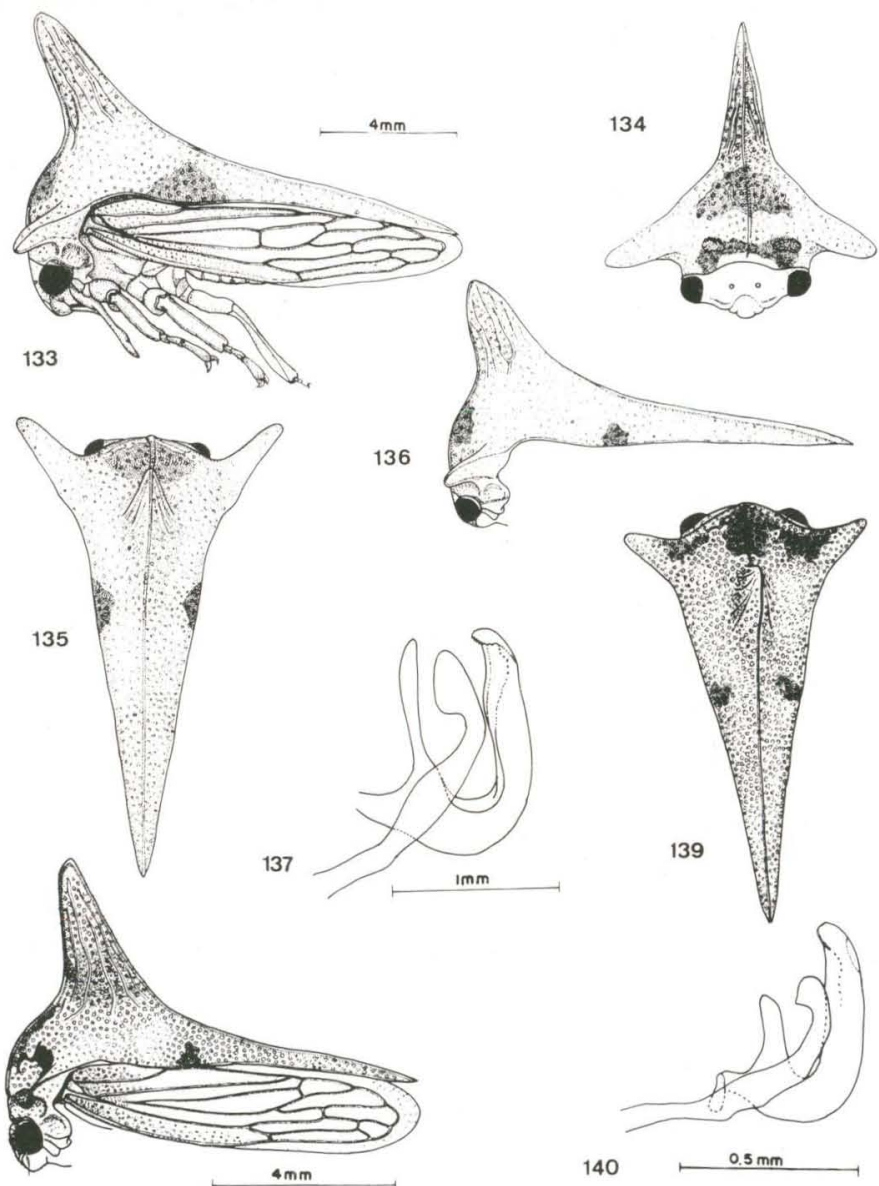

138

Figs 133-140. (133-137) Alchisme turrita: (133-135) fêmea; (136-137) macho. (138-140) Alchisme goiana sp.n.: (138-139) fêmea, (140) macho. 


\section{Alchisme goiana sp.n.}

Figs $138-140$

Medidas. Macho. Comprimento do corpo 8,42; largura da cabeça 2,67; distância entre os processos ad-umerais 4,92.

Diagnose. Processo dorsal bem desenvolvido, carenado, voltado para frente; metopídio com grande mancha escura transversal.

Descrição. Holótipo macho. Colorido geral castanho; cabeça com manchas escuras no vértice e próximo dos olhos; metopídio com mancha escura transversal estendida até a base dos processos ad-umerais; tégminas acastanhadas.

Cabeça subtriangular. Olhos globulares. Ocelos equidistantes entre si e dos olhos, situados sobre a linha imaginária que passa pelo centro dos olhos. Pós-clípeo piloso, carenado medianamente, com duas discretas intumescências laterais, adjacentes às margens internas dos lóbulos suprantenais.

Pronoto grosseiramente pontuado. Processo dorsal bem desenvolvido, carenado, voltado para frente, situado a acima dos úmeros. Processos ad-umerais bem desenvolvidos, robustos, dirigidos para fora e para frente; margens inferiores alcançando os olhos.

Coxas II com espinho basal; tíbias III com setas cuculadas nas fileiras I e II; tarsos III reduzidos.

Tégminas com venação normal.

Abdome ligeiramente comprimido dorso-ventralmente.

Fêmea. Desconhecida.

Material examinado. Holótipo macho. BRASIL: Goiás/Jatai/

Faz[enda] Aceiro, X.1962. Exp[edição] do Dep[artamento] de Zoologia, USP (BMNH).

Comentários. A espécie aproxima-se de $A$. turrita, diferindo nos seguintes aspectos: processos ad-umerais curtos, não passando à frente da cabeça; processo dorsal mais longo; ápice dos parâmeros não dilatado.

Etimologia. Relativo à localidade-tipo.

\section{Alchisme antigua (Funkhouser, 1943)}

Figs 141-143

Umbonia antigua Funkhouser, 1943d: 462 (Loc. tipo: Guatemala). -Metcalf \& Wade, 1965: 541. Alchisme antigua; McKamey \& Deitz, 1996: 312.

Medidas. Fêmea/macho. Comprimento total 9,33/9,33; largura da cabeça 3,17/3,177; distância entre os processos ad-umerais 5,00/4,83.

Diagnose. Pronoto carenado; processo dorsal vertical, situado atrás dos úmeros.

Descrição. Fêmea. Colorido geral castanho-avermelhado; tégminas acastanhadas.

Cabeça subtriangular, finamente pontuada, pilosa. Olhos globulares. Ocelos equidistantes entre si e dos olhos, situados logo acima da linha imaginária que passa 
pelo centro dos olhos. Pós-clípeo globoso, com intumescências laterais adjacentes às margens internas dos lóbulos suprantenais.

Pronoto grosseiramente pontuado, com carenas laterais longitudinais irregulares. Processo dorsal vertical, com carenas pouco definidas, situado atrás dos úmeros. Processos ad-umerais projetados para os lados, relativamente curtos; margens inferiores não alcançando os olhos.

Coxas II com espinho basal; tíbias III com setas cuculadas nas fileiras I e II; tarsos III reduzidos.

Tégminas com venação normal.

Abdome ligeiramente comoprimido dorso-ventralmente.

Macho. Semelhante à fêmea; edeago em U, com espinhos diminutos subapicais dispostos em semicírculo.

Material examinado. Holótipo fêmea. Guatemala: Antigua, 26.II.1942 (USNM). Parátipo macho, com os mesmos dados do holótipo (USNM).

Comentários. FUNKHOUSER (1943) descreveu a espécie no gênero Umbonia, talvez devido a presença do processo dorsal vertical situado atrás dos úmeros. Apresenta entretanto, os processos ad-umerais projetados, asas posteriores com quatro células apicais, lóbulos jugais bem desenvolvidos e setas cuculadas nas fileiras I e II das tíbias III. MCKAMEY \& DEITZ (1996) transferiram-na para Alchisme.

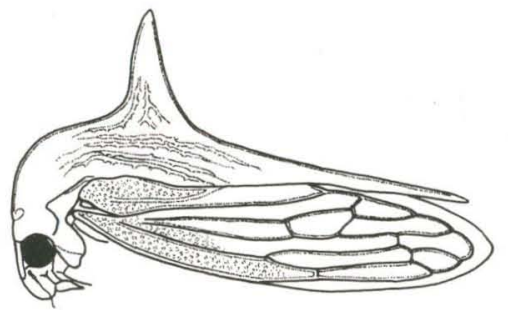

141

143

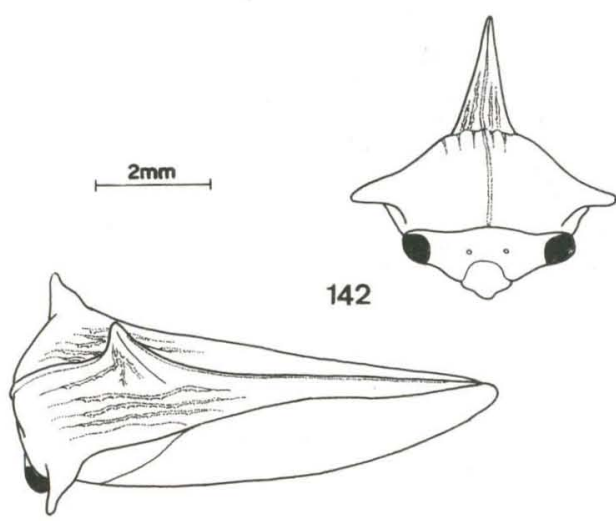

Figs 141-143. Alchisme antigua, holótipo fêmea.

\section{Espécies não examinadas}

\section{Alchisme intermedia (Distant, 1881), sp. reval.}

Fig. 149

Triquetra intermedia Distant, 1881: 223 (Loc. tipo: Colômbia, Bogotá). - Broomfield, 1971: 356. Microschema intermedia; Buckton, 1902: 102.

Alchisme intermedia; Funkhouser, 1927: 77. - Metcalf \& Wade, 1965: 559. - McKamey \& Deitz, 1996:

312 (= Alchisme nigrocarinata) (error). 

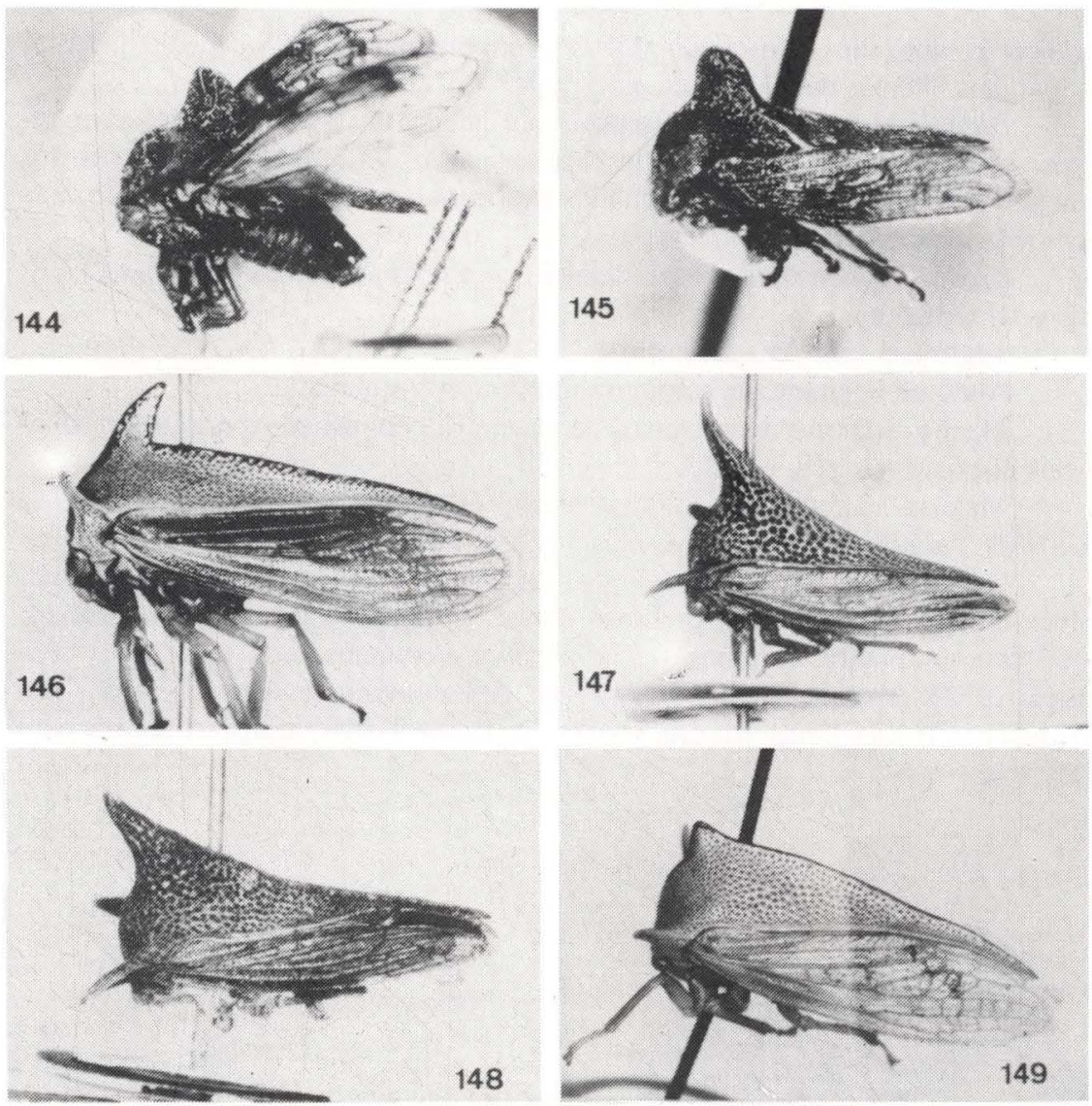

Figs 144-149. Fotos de tipos. (144) Alchisme laticornis, holótipo macho; (145) Alchisme pinguicornis, holótipo macho; (146) Alchisme recurva, holótipo fêmea; (147) Alchisme apicalis, holótipo fêmea; (148) Alchisme obscura, paralectótipo fêmea; (149) Alchisme intermedia, lectótipo fêmea.

\section{Triquetra intermedia sp.n.?}

Triquetra inermis, Fairm., var. ?

Closely allied to $T$. inermis, but differs by the anterior dorsal ridge of the pronotum being produced into a distinct, compressed, erect and somewhat anteriorly-directed spine-like process. Length, $14 \mathrm{~mm}$.

Hab.: Bogotá (Dr. Thième). Coll.: Oberthür and Distant."

Comentários. Triquetra intermedia sp.n.?: ao iniciar assim a descrição da espécie, Distant traduziu toda a sua incerteza quanto a validade dela. Comentando à respeito, afirmou que a sua forma é intermediária entre $T$. inermis Fairmaire e $T$. nigrocarinata Fairmaire. T. inermis se diferenciava pelo processo dorsal ausente ou obtusamente indicado; T. nigrocarinata pelo processo dorsal muito mais pronunci- 
ado. Em seguida, comentou que as três espécies poderiam ser apenas fases de um mesmo tipo.

METCALF \& WADE (1965) colocaram A. intermedia (Distant) como sinônimo de $A$. nigrocarinata (Fairmaire).

RESTREPO-MEJIA (1980) afirmou que $A$. inermis e $A$. nigrocarinata podiam ser separadas pelo exame da genitália dos machos.

Neste presente estudo, não se teve acesso ao exemplar-tipo de $A$. intermeda, entretanto obtivemos uma fotografia (slide) do mesmo. Comparando-se com os exemplares de $A$. inermis assim como o desenho apresentado por RESTREPO-MEJA (1980) de A. nigrocarinata, verificou-se que em A. intermedia o pronoto é mais elevado que de $A$. inermis e muito parecido com de $A$. nigrocarinata; Restrepo-Mejia. Se as evidências da estrutura da genitália dos machos apontam que $A$. nigrocarinata é uma variação de $A$. inermis, então $A$. nigrocarinata de Restrepo-Mejia seria A. intermedia. Revalidamos pois, A. intermedia (Distant, 1881).

\section{Alchisme truncaticornis (Germar, 1835)}

Hoplophora truncaticornis Germar, 1835: 244 (Loc. tipo: Brasil).

Triquetra truncaticornis; Fairmaire, 1846: 281.

Alchisme truncaticornis; Kirkaldy, 1904: 279. - Funkhouser, 1927: 79. - Metcalf \& Wade, 1965: 562.

- Restrepo-Mejia, 1980: 141. -McKamey \& Deitz, 1996: 313.

"Grisea, ocellato-punctata, humeris in dentem antrorsum versum, truncatum productis. Stethidio spina erecta, trigona. - Habitat in Brasilia. Bescke."

Comentários. A descrição original destaca que os úmeros são truncados no ápice. Alchisme cultellata também apresenta os úmeros truncados no ápice, mas não ocorre no Brasil; possui ainda inúmeras manchas escuras dispersas pelo pronoto, o que não acontece em A. truncaticornis.

\section{REFERÊNCIAS BIBLIOGRÁFICAS}

BUCKTon, G.B. 1901. A Monograph of the Membracidae. London, Lowell Reeve \& Co. Lmtd., 92p.

1902. A Monograph of the Membracidae. London, Lowell Reeve \& Co. Lmtd., p.93-180.

1903. A Monograph of the Membracidae. London, Lowell Reeve \& Co. Lmtd., 296p.

. 1905. Observations on some undescribed or little-known of Hemiptera-Homoptera of the family Membracidae. Trans. Linn. Soc. London, Zoology 9 (2): 329-338.

Distant, W.L. 1881. Notes on exotic Rhynchota. Entomologist monthly Mag. 17: 222-223.

FaIRMaIRE, L.M.H. 1846. Revue de la tribu des Membracides. Ann. Soc. Entomol. France 4 (2): 235-320.

FowLER, W.W. 1894a. Some new species of Membracidae. Trans. Entomol. Soc. London: 415-424.

1894b. Order Rhynchota: Suborder Hemiptera-Homoptera. Biol. Centr. 
Amer. 2: 1-173.

Funkhouser, W.D. 1927. Membracidae. General Catalogue of the Hemiptera.

1. Smith College, Northampton, Massachussets, 581p.

1930. New genera and species of Neotropical Membracidae. Jour. N.Y.

Entomol. Soc. 38:405-421.

455-482.

1951. Homoptera. Fam. Membracidae. In: P. WyTSMAN (Ed.). Genera

Insectorum. 208. Bruxelles, Louis Desmet Verteneuil, 383p.

Germar, E.F. 1835. Species Membracidum Musae E. F. Germari. Rev. Entomol.

Silbermann 3: 223-262.

GodING, F.W. 1929a. New Membracidae IX. Jour. N.Y. Entomol. Soc.37: 171174.

1929b. The Membracidae of South America and Antilles. IV. Subfamilies

Hoplophorioninae, Darninae, Smiliinae, Tragopinae (Homoptera). Trans.

Amer. Entomol. Soc. 55: 197-330.

1930. Membracidae in the American Museum of Natural History. Amer.

Mus. Nov. 421: 1-27.

KIRKaldy, G.W. 1901. Miscellanea Rhynchotalia. The Entomologist 34: 5-6.

1904. Bibliographical and nomenclatorial notes on the Hemiptera no. 3.

The Entomologist 37: 279-283.

McKameY, S.H. \& L.L. Deitz. 1996. Generic revision of the New World tribe Hoplophorionini (Hemiptera: Membracidae: Membracinae). Syst. Entomol. 21

(4): 295-342.

Metcalf Z. P. \& V. WAdE. 1965. General Catalogue of the Homoptera. A supplement to Fasc. I-Membracidae of the General Catalogue of Hemiptera. Membracoidea. 2 Sec. Raleigh, North Carolina State University, 1552p.

Restrepo-MeJIA, R. 1980. Membrácidos de Colombia-I. Revisión parcial de las especies dl género Alchisme Kirkaldy (Homoptera: Membracidae: Hoplophorioninae). Caldasia 13 (61): 103-164.

Signoret, V. 1863. Revision des Hémiptères du Chile. Ann. Soc. Entomol. France 8: 541-588.

SPINOLA, M. 1852. Historia fisica y politica de Chile segun documentos adquiridos en esta republica durante doce años de residencia en ella y publicada bajo los auspicios del supremo gobierno por Claudio Gay. Zoologia. Tomo setimo. Paris: 238-305.

STÅL, C. 1867. Bidrag till Hemipterernas systematik. Ofversigt af Svenska Vetenskaps Akademiens 24: 491-560.

-1 1869. Bidrag till Membraciderenas kannedon. Ofversigt af Svenska Vetenskaps Akadem. Forhand. 26:231-300.

WALKER, F. 1851. List of the specimens of Homopterous insects in the collection of the British Museum, part II. London, Edward Newmanm, p. 261-636.

1858. Supplement. List of the specimens of Homopterous insects in the collection of the British Museum. London, Edward Newman, 307p.

Recebido em 28.II.1997; aceito em 22.VII.1997. 